\title{
LEGAL EDUCATION AND THE REPRODUCTION OF HIERARCHY: A CONTEMPORARY ASIAN READING OF A SEMINAL TEXT
}

\author{
Dr Andra le Roux-Kemp*
}

\section{ABSTRACT}

Law schools are peculiar places occupied by, dependent on, associated with, and exerting influence on a myriad of institutions and stakeholders. From law students' efforts at mastering the allusive skill of legal reasoning to the challenges both tenured and untenured academic staff face in the neoliberalist higher education model where the legal profession and the consumers of the law school product exert increasing - and sometimes even impossible - demands, law schools and its populace have always been contested, hierarchical and image-conscious spaces. Indeed, as Ralph Shain noted in the Journal of Ideology in 2012, "[a]nyone who has suffered through law school would be grateful to have a good polemic against the institution". This article offers such a polemic against legal education in the Hong Kong Special Administrative Region. Over a period of four years, a selection of postgraduate law students from one of the (three) higher education institutions responsible for legal education and training in Hong Kong were asked to reflect upon their legal studies and future roles as legal professionals with reference to the 1983 self-published pamphlet by Duncan Kennedy, entitled "Legal Education and the Reproduction of Hierarchy: A Polemic Against the System". Kennedy's essay offered a critical analysis of the role of legal education in American social life at that time, and the manner in which it reproduced hierarchy in law, legal education, the legal profession, as well as in society generally. The narratives informing this article show that almost 40 years subsequent the publication of Kennedy's text, and in a jurisdiction with an altogether different social context and facing its own political turmoil and civil rights' aspirations, many parallels can be drawn with what Kennedy had observed in 1983.

Part I of this article sets the scene with a detailed overview of the legal education and training landscape of the Hong Kong Special Administrative Region from a legal-historical perspective to date. The discussion and analysis

* Associate Professor in Law, Lincoln Law School, University of Lincoln (United Kingdom); Member of the International Centre for Higher Education Management (ICHEM), University of Bath (United Kingdom). E-mail: alerouxkemp@lincoln.ac.uk 


\section{LEGAL EDUCATION AND THE REPRODUCTION OF HIERARCHY: A CONTEMPORARY ASIAN READING OF A SEMINAL TEXT}

then turn to the narratives of Hong Kong law students, offering a window into their experiences as (unintended) participants in the hierarchies of law and legal education in Hong Kong. Much more, however, can be gleaned from these narratives than just how these students perceive their present legal studies and future roles as legal professionals in the Hong Kong Special Administrative Region. These narratives also offer a critical reflection on Hong Kong's colonial past and present status as a Special Administrative Region of the People's Republic of China under the principle of "one country two systems" (Part II). Culture-specific values impacting on these students' legal studies and career decisions are revealed (Part III), and troublesome shortcomings in the current legal education and training landscape vis-à-vis the legal professional fraternity and political and socio-economic reality of Hong Kong are laid bare (Part IV). Much like Kennedy's 1983 essay failed to bring about any real change in how law schools go about their business as cogs in the apparatus of social hierarchy, the narratives informing this article also conclude on a rather sombre and futile note. Be that as it may. At least their voices have been heard and the seemingly inescapable power struggles noted. This too is an important function of the law and legal discourse.

Key Words: Legal education, legal profession, Hong Kong Special Administrative Region, Critical Legal Studies, Duncan Kennedy, hierarchy, narrative methodology.

\section{INTRODUCTION}

In 1983, Duncan Kennedy - Professor of Jurisprudence at Harvard Law School self-published a pamphlet entitled "Legal Education and the Reproduction of Hierarchy: A Polemic Against the System"." The preface to Kennedy's essay summarised his resolve in penning down this piece and is quoted in full here:

This is an essay about the role of legal education in American social life. It is a description of the ways in which legal education contributes to the reproduction of illegitimate hierarchy in the bar and in society. And it suggests ways in which left students and teachers who are determined not to let law school demobilize them can make the experience part of a left activist practice of social transformation.

The general thesis is that law schools are intensely political places, in spite of the fact that they seem intellectually unpretentious, barren of theoretical ambition or practical vision of what social life might be. The trade school

${ }^{1}$ Duncan Kennedy, Legal Education and the Reproduction of Hierarchy: A Polemic Against the System (New York University Press 2004) 1. 
mentality, the endless attention to trees at the expense of forests, the alternating grimness and chumminess of focus on the limited task at hand, all these are only a part of what is going on. The other part is ideological training for willing service in the hierarchies of the corporate welfare state.

To say that law school is ideological is to say that what teachers teach along with basic skills is wrong, is nonsense about what law is and how it works. It is to say that the message about the nature of legal competence, and its distribution among students, is wrong, is nonsense. It is to say that the ideas about the possibilities of life as a lawyer that students pick up from legal education are wrong, are nonsense. But all this is nonsense with a tilt, it is biased and motivated rather than random error. What it says is that it is natural, efficient and fair for law firms, the bar as a whole, and the society the bar services to be organised in their actual patterns of hierarchy and domination.

Because most students believe what they are told, explicitly and implicitly, about the world they are entering, they behave in ways that fulfil the prophecies the system makes about them and about that world. This is the link-back that completes the system: students do more than accept the way things are, and ideology does more than damp opposition. Students act affirmatively within the channels cut for them, cutting them deeper, giving the whole a patina of consent, and weaving complicity into everyone's story.

Resist!

Written at a time of acute civil rights consciousness in the United States of America, and as one of the first and seminal texts in the rise of the Critical Legal Studies movement, ${ }^{3}$ Kennedy's essay offered a critical analysis of the role of legal education in American social life and the manner in which it reproduced hierarchy in law, legal education, the legal profession, as well as in society generally. Of this hierarchy Peter Gabel said: "Duncan's book is not mainly about law school but about the reproduction of hierarchy within the society as a whole, in a way that actually constitutes the society by recruiting each new generation to become

${ }^{2}$ Kennedy (n 1) 15-16.

3 Of the Critical Legal Studies movement MDA Freeman explains as follows: "Critical legal studies (CLS) burst on the scene in the United States in the late 1970s with a series of conferences. It grew out of a dissatisfaction with current legal scholarship. It was more a ferment than a movement with those who identified as 'crits' a diverse group perhaps united only by their commitment to a more egalitarian society. Off-shoots are critical feminist jurisprudence, critical race theory, the Lat-Crit movement and other examples of outsider jurisprudence, such as 'queer jurisprudence" in MDA Freeman, Lloyd's Introduction to Jurisprudence (9th Edition Sweet \& Maxwell Thomson Reuters 2014) 1017. 


\section{LEGAL EDUCATION AND THE REPRODUCTION OF HIERARCHY: A CONTEMPORARY ASIAN READING OF A SEMINAL TEXT}

passive actors, role-players, in relationship to a self-legitimating set of ideas and patterns of deference and authority." Kennedy described this hierarchy as illegitimate for the following reasons:

Taking it on its own meritocratic terms, the game is stacked in favour of white males of the middle and upper middle class, so that power and reward are not distributed according to merit as merit would be revealed in a system of equal opportunity. Again, taking the system on its own merits, it is socially irrational: it is not necessary to have as many differences of capacity and role or as much inequality of power and reward as we now have, in order to achieve our social purposes. ...[And], [t]he attitudes, behaviours and relationships associated with legal hierarchy constitute, in themselves, a social perversion. ${ }^{5}$

He also preferred the phrase "reproduction of hierarchy" as opposed to "perpetuation of oppression" as it conveyed "the notion that the system is disintegrated, although not utterly chaotic". Kennedy explained:

[A]n organic metaphor - the system is there because it is reborn piecemeal in each generation, rather than being a conceptually graspable something that outsiders (capital, the ruling class, the state) impose and maintain. If you want to explain the status quo, you have to go into the details of how people, new people in each generation, learn to be little white middle class males, teenaged black welfare mothers living in public housing projects, and so forth. There's more to it than the state, or one's relation to the means of production... ${ }^{6}$

Kennedy's hypothesis of how legal education feeds the hierarchy of the system is set out in his introduction to Chapter Two of the pamphlet, which is entitled "The Ideological Content of Legal Education".

One can distinguish in a rough way between two aspects of legal education as a reproducer of hierarchy. A lot of what happens is the inculcation through the formal curriculum and the classroom experience of a set of political attitudes toward the economy and society in general, toward law, and toward the possibilities of life in the profession. These have a general ideological

4 Peter Gabel, "The Spiritual Foundation of Attachment to Hierarchy", in Kennedy (n 1) 157-158.

5 Kennedy (n 1) 94-95.

6 Kennedy (n 1) 95. 
significance, and they have an impact on the lives even of law students who never practice law. Then there is a complicated set of institutional practices that orient students to willing participation in the specialized hierarchical roles of lawyers. In order to understand these, one must have at least a rough conception of what the world of practice is like.

He further explained as follows in the introduction to his Chapter Three, which is entitled "Hierarchies of the Legal Profession":

Throughout their legal education, students are engaged in reconceiving themselves and the legal profession. Partly this is an affair of knowledge. Students find out things about the bar and about themselves that they didn't know before, and the process has a direction - it is a process of loss, of possibilities foreclosed. Knowledge of professional life renders irrelevant capacities you have but will not be allowed to use. Newly discovered incapacities of the self make it impossible to play roles it was easy to fantasize as a college student. ${ }^{8}$

Almost 40 years later, and in the city of Hong Kong, an altogether different jurisdiction with a different social context and facing its own political turmoil and civil rights' aspirations, I asked postgraduate law students (JD, LLM and PhD students) enrolled for my Jurisprudence course in the years 2016, 2018 and 2019 to reflect on their legal studies with reference to the Duncan Kennedy text. The goal of this exercise was twofold: In a society where everything happens fast, sometimes too fast even to contemplate motivations or to consider consequences or alternatives, I wanted the students, by way of a compulsory assignment, to think through their raison d'être for studying law, their current experiences as law students, and also their future role - most probably as (commercial) legal practitioners - in Hong Kong society. But what shared experiences or echoes of acknowledgement, if any, could 21st century Hong Kong law students have with a Harvard Law Professor's musings that predate most of their (the Hong Kong students') birth?

The Kennedy text was conceived and ultimately published amidst a series of dramatic historical events and epochs impacting on the people of the United States of America - including the civil rights movement (1950s and 1960s), the Vietnam War (1954-1975) and the Cold War crisis (1947-1991). A key feature of contemporary Hong Kong, on the other hand, is its duality: The territory commonly

7 Kennedy (n 1) 30.

8 Kennedy (n 1) 49. 


\section{LEGAL EDUCATION AND THE REPRODUCTION OF HIERARCHY: A CONTEMPORARY ASIAN READING OF A SEMINAL TEXT}

known as Hong Kong was acquired by the British Empire as a product of the First Anglo-Chinese War (1839-42), also known as the "Opium War". 9 The legal system established in Hong Kong under British rule is a direct replication, or transplantation of the laws of England and Wales, the contours of which have largely remained the same during the 153 years of British sovereignty over Hong Kong, and also to date. The political system of Hong Kong can be described as a negotiated truce, the product of protracted negotiations between the People's Republic of China and Britain from September 1982 to 1 July 1997, when Hong Kong was finally retroceded to the People's Republic of China. ${ }^{10}$ In terms of the Sino-British Joint Declaration formally signed on 19 December 1984 and ratified in May $1985,{ }^{11}$ both powers agreed, inter alia, that Hong Kong be transferred from Britain to the People's Republic of China on 1 July 1997, that Hong Kong will exist as a Special Administrative Region of the People's Republic of China under the principle one country two systems, that it will enjoy a high degree of autonomy, except in foreign and defence affairs, that it be vested with an executive, legislative and independent judicial power, and that the common law legal system as it existed at that time in Hong Kong will remain unchanged. ${ }^{12}$ It was also agreed that Hong Kong will enjoy the free flow of capital and freely convertible currency, and that these (and other) commitments on the part of the Chinese government to Hong Kong be pledged under a Basic Law for the Special Administrative Region to be promulgated by the National People's Congress of the People's Republic of China. It was furthermore agreed that this negotiated status of the Hong Kong Special Administrative Region will remain unchanged for a period of 50 years (up to 2047). ${ }^{13}$ Under the one country two systems principle therefore, Hong Kong not only enjoys a different legal system from that of the People's Republic of China, ${ }^{14}$ but also boasts laissez-faire capitalism and is consistently rated as the freest

\footnotetext{
9 Steve Tsang, A Modern History of Hong Kong (I. B. Tauris \& Co Ltd 2004) 3.

10 Tsang (n 9) 18.

11 The Sino-British Joint Declaration of Beijing in "People's Republic of China-United Kingdom: Agreement on the Future of Hong Kong" (1984) International Legal Materials Vol. 23, 1366.

12 Tsang (n 9) 226.

13 Tsang (n 9) 226.

14 The legal system of the People's Republic of China is of the civil law tradition and can be described as an amalgamation of laws from countries with civil legal systems, notably the Bundesrepublic Deutschland, as well as the culmination of centuries of legal reform and development of a socialist legal system with Chinese characteristics. See generally Albert Hung-Yee Chen, An Introduction to the Legal System of the People's Republic of China (4th edn LexisNexis 2011).
} 
economy in the world. ${ }^{15}$ Leo F. Goodstadt described the coming about of Hong Kong's distinctive economic and social status and ongoing development (which will be elaborated upon in Part IV below) as follows:

History makes a larger contribution to shaping day-to-day government behavior in Hong Kong than in most modern societies. For all its differences with British colonialism, China's leaders recognised that Hong Kong had developed political and business systems essential to a flourishing capitalism environment. As a result, the economic and social policies and institutions that evolved under British rule have been entrenched in the Basic Law, the blueprint for post-colonial Hong Kong. This constitutional document also provides for the continuing dominance of the business community in public affairs. Thus, Hong Kong is locked by Chinese law into arrangements inherited from history, which makes the past a matter of immediate importance rather than academic interest. $^{16}$

The Hong Kong Special Administrative Region, an enigmatic metropolis, the product of a dying empire and now on the margins of an ancient and reasserting empire of kin, can therefore not be studied without noting its many binaries and dichotomies. It is the city where East meets West, where a common law legal system prevails in Chinese territory alongside the Chinese socialist civil law legal system, where communism meets limited democracy, and where overt capitalism stands in stark contrast to the Chinese socialist and communist policies.

Curiously, despite these contextual, spatial and temporal differences between modern day Hong Kong and Kennedy's United States of America of almost 40 years ago, the Hong Kong law students who participated in this exercise were ad idem with Kennedy that getting into a law school (in Hong Kong) assuredly promises a training for hierarchy and reproduces the existing hierarchies prevalent in the city's legal system and its laws. Of this, one student remarked as follows:

It baffles me as to why nobody in the right position has given any thought on breaking this vicious loop. (JD student, 2018)

15 Government of the Hong Kong Special Administrative Region, "Press Release: Hong Kong once again regarded as freest economy in the world" (26 September 2018) <https:// www.info.gov.hk/gia/general/201809/26/P2018092600318.htm> accessed 31 March 2020. 16 Leo F Goodstadt, A Fragile Prosperity: Government Policy and the Management of Hong Kong's Economic and Social Development HKIMR Working Paper No. 01/2009, 1 (January 2009) <https://papers.ssrn.com/sol3/papers.cfm?abstract_id=1336442\& download=yes $>$ accessed 31 March 2020. 


\section{LEGAL EDUCATION AND THE REPRODUCTION OF HIERARCHY: A CONTEMPORARY ASIAN READING OF A SEMINAL TEXT}

Some of the hierarchies identified by the Hong Kong students were quite similar to those mentioned by Duncan Kennedy in his seminal 1983 text. For example, the social prestige and status associated with studying law are certainly also evident in the Hong Kong context. In his 1983 pamphlet Kennedy remarked that studying law has a social meaning:

Almost everyone whose parents were not members of the professional/ technical intelligentsia seems to feel that going to law school is an advance, in terms of the family history. ...it is rare for parents to actively disapprove of their children going to law school, whatever their origins. So taking this particular step has a social meaning, however much the student may reject it, and that social meaning is success. ${ }^{17}$

Likewise, Hong Kong students also remarked upon the social prestige and status associated with studying law:

It seems that most of us are not directly driven by studying law itself. We just regard legal education as a shortcut to climb up the social ladder, instead of as an end. (JD student, 2019)

...law study and law-related jobs are culturally seen as professional and honorable in Chinese society. In Hong Kong, a lawyer is often being addressed by his/her title, instead of name, such as 'Lawyer x' (x律師) instead of 'Ms. X' (x小姐). A highlight in occupational title gives attention to one's respectable social status. (JD student, 2019)

And many students also noted the role their parents and family members played in their decision to pursue legal studies:

...I have proposed to study a postgraduate degree in Life Sciences specialising in Stem Cell research, they [mother and brother] both strongly disagreed with such pursuit of interest in the science education where there is trivial amount of perceived social or economic benefits for my career in life. It is in that sense the legal education has become a monetizing tool for my career path and a possession of elitism to achieve a higher social status in Hong Kong. Based on my personal experience, the cultural capital of receiving a legal education would definitely direct me to become a member of the professional intelligentsia to symbolize my success at least in preserving my family's cultural capital and perhaps to gain recognitions from my friends and the society. (JD student, 2018)

${ }^{17}$ Kennedy (n 1) 18-19. 
...most parents put fame and success in front of interest to determine their children's subject in university. If their child gets good grades in the public exam and is good at arts and language, they will definitely enrol their children to studying law, despite the real interest of the child is fashion design or education. It seems going to law school equals success and fortune in the future. It may be true for some students, however, many other students who do not adapt to the environment and stress of the law school are likely to drop out of the course or even school. (JD student, 2016)

In fact, the perceived social prestige and status associated with studying law and entering the legal profession, and the potential gain this may hold for a "family's cultural capital", may be even more overt in the East where filial piety, ${ }^{18}$ a key virtue in Chinese and other East Asian cultures, amplifies the parental and familial influences and pressures on the life decisions of students.

It is not unfamiliar to describe Hong Kong parents as 'Tiger parents' or 'Helicopter parents'. They demand their children to learn diversely and become academically successful. Most of them believe that attending medical or law schools is the only way to enter the upper echelons of society and they are proud of what they are going to be. (JD Student, 2018)

Like Duncan said, almost all parents will be proud of their children if their children can study at law school. When I was admitted by law school, my parents and relatives were very happy, they thought "lawyer" is the symbol of social elite. When people know I major in law, they always make fun of me and say "you must be rich in the future". Once law students enter into law school, we are tagged as "middle class" people. After law students graduated, the students from top law school will gain better opportunity to work for the top law firm and earn more money. (JD Student, 2018)

Hong Kong as being a part of the Asian society roots heavily in elitism. Surely the west does as well, but with a smaller degree. Studying Law is so legitimate that no relatives will dare to challenge. But how about studying Sociology? The perception that lawyers fight for justice mystifies them. Justice goes beyond fair trial and evidential rule. Justice that can be summarized into written rules is minimal - it is a lesser evil that few is better than none. In

18 The Confucian idea of filial piety "is constructed on the simple fact that one's body exists solely because of one's parents" or put differently, that "individuals' lives are the continuation of their parents' physical lives". See generally, Kwang-Kuo Hwang "Filial Piety and Loyalty: Two Types of Social Identification in Confucianism" (1999) 2 Asian Journal of Social Psychology 163-183, 169. 


\section{LEGAL EDUCATION AND THE REPRODUCTION OF HIERARCHY:}

A CONTEMPORARY ASIAN READING OF A SEMINAL TEXT

scraps of justice, barrister is found. Yet, solicitor in fact does little with justice. After all, billable hours speak. (JD student, 2018)

Other factors contributing to the distinct social meaning that attach to the study and practice of law in modern-day Hong Kong, and compared with the mid-1900s United States of America described by Kennedy, include the impact of Hong Kong's extreme capitalist ideology on law and legal practice, which places the interests of business and economic progress above all, even above that of social development and rudimentary social justice. This was described by a Hong Kong student as follows:

As a city largely depends on its financial industry, Hong Kong offers limited career choices, giving rise to internal hierarchy among them [the students] mainly based on their closeness to the financial industry. In this way, legal profession in Hong Kong, especially law firms practicing commercial law, enjoys a socially constructed high status. It is in this social environment that legal education in Hong Kong works to reproduce the hierarchy through students and professors. (JD student, 2019)

(The impact of this "business comes first" attitude on the legal curriculum of Hong Kong law degrees and the future career paths of its law students will be elaborated upon further in Part IV of this article.) In addition, the inherent dichotomy posed by the one country two systems principle also contributes to a heightened sense of importance being attached to the legal profession in Hong Kong. This is because the common law system in the Hong Kong Special Administrative Region is often placed in juxtaposition to the civil law system of the People's Republic of China, in a manner by which Hong Kongese people claim superiority in terms of their legal system having the rule of law versus the absence thereof on the Mainland. The concept rule of law specifically is often used by Hong Kongese people as a "binary and moralistic divisive tool used to separate Hong Kong people from that of the People's Republic of China", ${ }^{19}$ a constitutive rhetoric or ideology, in other words, to establish or reaffirm an identity, including a legal identity, that is distinct and different from that of the "other" Chinese and the People's Republic of China. ${ }^{20}$

19 Andra le Roux-Kemp, "A legal-historical chronicle of rule-of-law narratives in Hong Kong" in Joshua C Tate, José Reinaldo de Lima Lopes and Andrés Botero-Bernal (eds), Global Legal History - A Comparative Law Perspective (Routledge 2018) 158, 169.

${ }^{20}$ See generally, Le Roux-Kemp (n 19) 158-175. 
HK court was blessed with an independent judicial power which power is always a symbol of superior identity. Thus indirectly raised the status of judges, lawyers and the people with legal background to be more superior than the others. The protective mindset causes the exiting 'beneficiary' created a high barrier to entry through the education system. (JD student, 2018)

These and other hierarchies in law and legal education in the Hong Kong Special Administrative Region, three decades after Kennedy's seminal text and approximately 7500 nautical miles east from where Kennedy penned his experiences and observations, are the focus of this article. In addition to providing an overview of the legal education and training landscape of the Hong Kong Special Administrative Region, as well as its legal profession (Part II), this article allows for the voices of law students to speak about their experiences as (unintended) participants in the hierarchies of law and legal education in Hong Kong (Part III). The narratives of Hong Kong law students in this article lay bare the existence and acute reality of hierarchy in law and legal education in contemporary Hong Kong. These hierarchies are, like much of life in Hong Kong today, remnant of Hong Kong's colonial history, paused in time and space by the negotiated truce of the one country two systems principle (until 2047), and reproduced - as if on a loop - to make for a particularly intense experience. In recognising this, many law students voiced a sense of futility in trying to escape from the structural violence of hierarchy in law and legal practice in Hong Kong:

If there is any fact about legal education in Hong Kong, reproduction of hierarchy would be one. ...The reproduction of hierarchy in law school is a typical Hong Kong phenomenon, rather than something peculiar to law or even to the professions, and the other institutions or the whole society strongly resemble. Hong Kong is a highly status-conscious society. The whole society accepts, even admires, hierarchy. More than most other places in the world, Hong Kong people intend to be proud of fighting for one's good life, to despise people who failed in the process, and to respect rich people. Young people come to law school for the opportunity of social mobility. Therefore, unlike the U.S. where civil rights movement developed in the mid-1900s, the criticism and resist against hierarchy, in legal education or beyond it, has no shot Hong Kong. (LLM student, 2018)

In Part IV of this article, the reproduction and further extension of these hierarchies in legal practice and the legal profession of Hong Kong will be considered, and in Part V, some of the negative consequences of these hierarchies in legal education and training, legal practice and the legal profession in Hong 
Kong will be elaborated upon. The whole of this article is informed by the (anonymised) observations and remarks from postgraduate law students from the School of Law, City University of Hong Kong, during the 2016, 2018 and 2019 academic years. While these observations and remarks from students are indeed limited in this sense - that is not representing the voice of all law students and of all the tertiary education institutions responsible for legal education and training in Hong Kong - it nonetheless remains relevant and representative of law student experiences and perceptions in the Hong Kong Special Administrative Region. The primary objective of this article is to lay bare the existence and acute reality of hierarchy in law and legal education in contemporary Hong Kong, in the same manner in which Duncan Kennedy raised these (and other issues) in his selfpublished pamphlet entitled "Legal Education and the Reproduction of Hierarchy: A Polemic Against the System" in 1983. ${ }^{21}$ And similar to Kennedy's text having been conceived and published amidst a series of dramatic historical events and epochs impacting on the people of the United States of America at that time, this article is also conceived with due regard to the ongoing concerns for human rights and basic freedoms in the Hong Kong Special Administrative Region. The institutions and stakeholders of law should, after all, acknowledge their agency and be held responsible for the Lebenswelt to which they contribute.

\section{A BRIEF HISTORY AND OVERVIEW OF LEGAL EDUCATION IN THE HONG KONG SPECIAL ADMINISTRATIVE REGION}

The legal system of the Hong Kong Special Administrative Region is a direct replication or transplantation of the laws of England and Wales, the erstwhile colonial power of Hong Kong. The contours of this legal system have largely remained the same during the 153 years of British sovereignty over Hong Kong from 1842 to the retrocession of Hong Kong to the People's Republic of China on 1 July 1997. While the inherited legal system and laws of England and Wales have since acquired a distinctive Hong Kong character by way of legal reform and development, it nonetheless mirrors many aspects of its colonial heritage, both in terms of its roots and its continued development. This is also true of legal education in Hong Kong.

What is interesting to note with regard to the British acquisition of and presence in Hong Kong is that this territory was not occupied by or expanded upon by the British with a view to colonise, but rather for diplomatic, commercial and

21 Kennedy (n 1) 1. 
military purposes; "an imperial outpost at the edge of the Chinese Empire". ${ }^{22}$ Not being a settlement colony, few people in Hong Kong were familiar with English law. ${ }^{23}$ Thus, during Hong Kong's early colonial years, all legal professionals whether in government service or private practice - were expatriates, trained in England. ${ }^{24}$ If a local Hong Kong resident wanted to enter the legal profession as either a barrister or a solicitor, that local resident first had to obtain the professional credentials necessary for practising as either a barrister or a solicitor in the United Kingdom, before being eligible to practice law in Hong Kong. ${ }^{25}$ The admission requirements for practising law as either a barrister or a solicitor in the United Kingdom at that time (late nineteenth to mid-20th century) essentially entailed the following (although it must be noted that there was much flux during this period due to legal reform efforts aimed at legal education and the regulation of the professions): Aspiring barristers had to secure a two-year apprenticeship (called pupillage) with an existing barrister at one of the four Inns (Lincoln's, Gray's, Inner Temple or Middle Temple), complete a prescribed service term which involved various collegiate activities and vocational training, and pass a compulsory bar examination administered by their Inn. The bar examination consisted of two parts; aspiring barristers who had graduated with a university degree - usually a degree in law or classics from Oxford or Cambridge University were exempted from Part I of the examination, while all intending barristers ultimately had to sit for and pass Part II of the examination. ${ }^{26}$ Aspiring solicitors, on the other hand, had to secure a five-year apprenticeship (called articles) if they did not hold a university degree, and a three-year apprenticeship (articles) if they held a university law degree. ${ }^{27}$ In addition to a one-year full-time or two-year parttime legal studies course with qualifying examinations for those who did not hold

\footnotetext{
22 Tsang (n 9) 20 and 26.
}

23 Johannes Chan, "The Law Society's Power to Introduce a Common Entrance Examination” (2018) 48(1) Hong Kong Law Journal 1, 2.

24 Luke Marsh and Michael Ramsden, "Developments in Hong Kong Legal Education" (2016) 3(2) Asian Journal of Legal Education 144, 146; Standing Committee on Legal Education and Training "Comprehensive Review of Legal Education and Training in Hong Kong: Final Report of the Consultants" (April 2018) 14 <https://www.info.gov.hk/ gia/general/201809/26/P2018092600318.htm> accessed 31 March 2020.

25 Marsh and Ramsden (n 24) 146.

26 Richard Abel, The Legal Profession in England and Wales (Basil Blackwell 1988) 24-64; for the present admission requirements to practice law as a barrister in the United Kingdom see <https://www.barcouncil.org.uk/> accessed 31 March 2020.

27 In 1963 the period was reduced from five years to four years for school leavers and from three years to two years for university graduates and other mature candidates with extensive work experience. Abel (n 26) 149. 


\section{LEGAL EDUCATION AND THE REPRODUCTION OF HIERARCHY: A CONTEMPORARY ASIAN READING OF A SEMINAL TEXT}

a law degree specifically or any degree at all, and which constituted Part I of the Law Society's Final Examinations, all aspiring solicitors also had to sit for and pass an intermediate examination (Part II), and complete such professional skills and other courses as the Law Society prescribed during the course of their training contracts (articles). ${ }^{28}$ It is evident, therefore, given the requisite protracted periods of study and training in the United Kingdom, that the career path of legal professional was realistically only available to local Hong Kong families of wealth. $^{29}$

Yet, as the colonial territory of Hong Kong transformed from "...a group of sleepy fishing villages into a crossroads of international trade", 30 systems and institutions necessary to maintain its growth and development were established. ${ }^{31}$ The rapidly growing economy ultimately demanded legal professionals "trained for practice in Hong Kong and, specifically, for Hong Kong". ${ }^{32}$ This became all the more necessary with the establishment of the Hong Kong Supreme Court in 1843, and the promulgation of the Admission of Practitioners in Supreme Court Ordinance No. 13 of 1856. This legislation was introduced to provide, inter alia, for the admission of legal practitioners to the Hong Kong Supreme Court. Of the admission requirements to practice law in Hong Kong in terms of this legislation, Johannes Chan noted that it was "rather loose":

Apart from attorney, solicitors and proctors who were admitted in any of Her Majesty's colonies, any person who had served [for a period of three years] as a registrar, clerk of the Supreme Court or a judge, interpreter of the Court, clerk of the Attorney General, a clerk of the peace or an articled clerk would be eligible for admission, subject to an examination of their fitness to be admitted. The power of admission, as well as the power to remove and strike off from the roll of attorney, solicitor, proctor or interpreter, was vested in the Supreme Court. ${ }^{33}$

\footnotetext{
28 Abel (n 26) 139-168, particularly 142; for the present admission requirements to practice law as a solicitor in the United Kingdom see <https://www.lawsociety.org.uk/lawcareers/becoming-a-solicitor/qualifying-as-a-solicitor/> accessed 31 March 2020.

29 Marsh and Ramsden (n 24) 146.

${ }^{30}$ Marsh and Ramsden (n 24) 146, quoting from Hong Kong Tourism Board, History $<$ http://www.discoverhongkong.com/eng/plan-your-trip/traveller-info/about-hong-kong/ history.jsp> accessed 31 March 2020.

31 Marsh and Ramsden (n 24) 146.

32 Marsh and Ramsden (n 24) 146.

${ }^{33}$ Chan (n 23) 2; see also the Admission of Practitioners in Supreme Court Ordinance No. 13 of 1856 and the subsequent Legal Practitioners Ordinances No. 1 of 1871.
} 
Thus, to practice law in Hong Kong in these early colonial years of the territory and subsequent the promulgation of the Admission of Practitioners in Supreme Court Ordinance No. 13 of 1856, the formal English route for acquiring the requisite professional credentials remained, whilst an alternative route was created for certain categories of civil servants or articled clerks who had served for a period of three years in Hong Kong. For both those qualified in the United Kingdom as well as those who now met the Hong Kong service requirement as set out above, a local examination was introduced, focussing on the fitness of the eligible candidates; "their character, conduct, learning, and length and assiduity of service, and their other credentials, and conforming themselves so far as may be practicable to the regulations by which the examinations of candidates for admission to practice as attornies [sic] and solicitors of the Courts of Westminister are governed and directed". 34

In terms of tertiary education in Hong Kong, the foundation stone for the first university - the University of Hong Kong - was laid by Sir Frederick Lugard on 16 March 1910, and on 11 March 1912 the university was officially opened. ${ }^{35}$ At its founding, the University of Hong Kong "viewed itself as having a wider role in relation to China's modernisation, hoping to offer students coming from China a 'liberal, secular, Western education which would, inter alia, fit them for careers in the Imperial Civil Service" ". ${ }^{36}$ With no intention to "enter the business of legal education for intended practitioners in Hong Kong", Arts, Engineering and Medicine became this university's first faculties. ${ }^{37}$ Yet, by the early 1960s, "leading figures in Hong Kong's society - most prominently, Vice Chancellor Sir Lindsay Ride of the University of Hong Kong (HKU) and President P.A.L. Vine of The Law Society of Hong Kong - increasingly voiced their support for a local law curriculum". ${ }^{38}$ This was largely due to the "growing dissatisfaction with the expense and inefficiency of the existing methods of legal qualification, shipping the best and brightest away to learn how to practice law in a jurisdiction markedly different from Hong Kong". 39 Moreover, the promulgation of an extensively

\footnotetext{
34 Section 3 of the Admission of Practitioners in Supreme Court Ordinance No. 13 of 1856; also see the Legal Practitioners Ordinance No 1 of 1871.

35 University of Hong Kong, The Early Years <https://www.hku.hk/about/universityhistory/the-early-years.html> accessed 31 March 2020.

36 Marsh and Ramsden (n 24) 146.

37 Marsh and Ramsden (n 24) 146; University of Hong Kong (n 35).

38 Marsh and Ramsden (n 24) 146-147; Standing Committee on Legal Education and Training (n 24) 15.

39 Marsh and Ramsden (n 24) 147.
} 


\section{LEGAL EDUCATION AND THE REPRODUCTION OF HIERARCHY: A CONTEMPORARY ASIAN READING OF A SEMINAL TEXT}

revised and amended Legal Practitioners Ordinance Cap 159 of 1964 afforded more powers to the professional regulatory bodies for solicitors and barristers which had, by that time, already been established for legal practitioners in Hong Kong. ${ }^{40}$

The "Hongkong Law Society" (since 1969 known as the Law Society of Hong Kong) was established on 8 July 1907, as a company limited by guarantee, and was first noted in the 1923 version of the Legal Practitioners Ordinance No. 1 of $1871 .{ }^{41}$ Today, the Law Society of Hong Kong is responsible, by virtue of the Hong Kong Legal Practitioners Ordinance Cap 159, for, inter alia, the regulation and administration of matters such as admissions to practise as a solicitor in Hong Kong, the issuing of practising certificates, overseeing compliance with the practising rules, and it also has extensive disciplinary powers over the practising profession in the event of failure to comply with the relevant rules. ${ }^{42}$ The Bar Association of Hong Kong, in turn, was established in 1949, and as is the case with the Law Society, the Bar Association administers the process of dealing with applications for admission, collection of fees, issuance of practising certificates and also acts as a disciplinary tribunal when required. ${ }^{43}$

In the same year the revised and amended Legal Practitioners Ordinance Cap 159 of 1964 was promulgated (i.e. 1964), the Department of Extra-Mural Studies at the University of Hong Kong began offering evening courses for the University of London's External LLB Degree, allowing successful students to be exempted from Part 1 of the English professional examinations, and thereby "providing the

40 For example, in terms of the Legal Practitioners Ordinance Cap 159 of 1964, the powers of the Chief Justice of the Hong Kong Supreme Court to regulate the practice of law and legal professionals in Hong Kong were partially transferred to the Committee of the Law Society (later renamed as the Council of the Law Society). While the powers to make rules regarding the admission of solicitors and barristers and the registration of notaries public, practicing certificates, fees and documents and rules relating to disciplinary proceedings against barristers remained vested with the Chief Justice, the Law Society became endowed with rule-making capabilities relating to a variety of matters concerning solicitors, their qualification and their practice. Such rules made by the Committee of the Law Society, however, remained subject to the approval of the Chief Justice. A Cost Committee of the Law Society was furthermore empowered to make rules prescribing the remuneration payable to a solicitor in respect of his or her non-contentious practice as defined in the provisions of the Ordinance. Chan (n 23) 2-3.

${ }^{41}$ Section 1 of the Legal Practitioners Ordinance No. 1 of 1871; Standing Committee on Legal Education and Training (n 24) 19.

42 Standing Committee on Legal Education and Training (n 24) 19.

43 Standing Committee on Legal Education and Training (n 24) 19-20. 
privileges of a UK law degree at greatly reduced expense". ${ }^{44}$ Although a significant intermediate step, this Hong Kong External LLB Degree remained a temporary solution to the lack of a local legal education, the programme's ability to secure the necessary resources, including faculty staff, remained limited, and while graduates of the External Degree wishing to qualify as solicitors could ultimately meet the requirements for admission to practice in Hong Kong by passing Part II of the examination hosted by the Hong Kong Law Society, those seeking admission as barristers still needed to travel to England to acquire the necessary professional credentials and sit for the final Bar examination. ${ }^{45}$ Moreover, the External LLB Degree remained a law qualification designed to meet English needs, and not the unique needs and conditions of Hong Kong. ${ }^{46}$ As a consequence, the then Chief Justice Sir Michael Hogan appointed the First Working Party on Legal Education in 1966, to consider possible long-term solutions to the question of a local legal education in Hong Kong. ${ }^{47}$

The First Working Party - chaired by the senior puisne judge and including representatives from the attorney-general, the Hong Kong Bar Association, the Law Society of Hong Kong, the University of Hong Kong and the Chinese University of Hong, the latter institution which was established in 1963 - issued its report and recommendations in June $1967 .{ }^{48}$ Principal among its findings was "the introduction in Hong Kong of a system of teaching and training in legal subjects, which would enable candidates to qualify for admission, whether as a barrister or a solicitor, entitled to practice in Hong Kong without the necessity of proceeding overseas in order to obtain any further qualification". ${ }^{49}$ In addition to addressing the burden and expense of the overseas legal qualifications, the First Working Party also recommended the elimination of subjects of English law not relevant to Hong Kong, whilst creating the flexibility to include subjects of more practical

\footnotetext{
44 Also see Rule 14 of the Hong Kong Students Rule 1964, made pursuant to section 73 of the Legal Practitioners Ordinance and which set out the qualifications required for admission, namely that the candidate (1) had served the requisite articled clerkship and (2) had either passed or been exempted from Part 1 of the overseas qualifying examination set by the English Law Society and had passed Part II of the same examination. Marsh and Ramsden (n 24) 147; Chan (n 23) 3.

45 Marsh and Ramsden (n 24) 147; Standing Committee on Legal Education and Training (n 24) 15.

46 Marsh and Ramsden (n 24) 147.

47 Marsh and Ramsden (n 24) 147.

48 Marsh and Ramsden (n 24) 147; Standing Committee on Legal Education and Training (n 24) 16.

49 Marsh and Ramsden (n 24) 147; Standing Committee on Legal Education and Training (n 24) 16.
} 


\section{LEGAL EDUCATION AND THE REPRODUCTION OF HIERARCHY: A CONTEMPORARY ASIAN READING OF A SEMINAL TEXT}

importance in the Hong Kong context, such as Chinese Customary Law. ${ }^{50}$ Courses, it was submitted, " “...designed to qualify a man to practice law in Hong Kong must also educate him in Hong Kong practice"." 51

Embracing the recommendations of the First Working Party, the University of Hong Kong established a Department of Law and developed an honours degree in law, better suited for meeting the needs of the local legal community. ${ }^{52}$ In 1968 , the University Grants Committee (UGC) - the administrative body coordinating government funding to higher education institutions in Hong Kong - approved the proposed full-time, three-year LLB degree programme and law curriculum of the University of Hong Kong, and in 1969 the first LLB students were enrolled for local legal education and training. ${ }^{53}$ What remained unaddressed, however, was the question of local examinations and practical training for admission to practice as either a solicitor or a barrister in Hong Kong, as well as whether the local honours degree in law were to be reciprocally recognised by The Law Society of England as a valid qualification to practice law in the United Kingdom. ${ }^{54}$ A Second Working Party was subsequently established in 1969 to consider these matters. ${ }^{55}$ The question of reciprocity was answered quickly, with The Law Society of England agreeing to recognise the three-year LLB degree programme offered by the Department of Law of the University of Hong Kong. ${ }^{56}$ With regard to the issue of local examinations and practical training for admission to practice as either a solicitor or a barrister in Hong Kong, the Second Working Party noted that "it was essential that law graduates receive a period of additional education and training after receiving their LLB, before becoming eligible to practice as a full-fledged member of the legal profession". ${ }^{57}$ A Postgraduate Certificate in Laws (PCLL), a one-year full-time course providing professional legal training, and matching the

50 Marsh and Ramsden (n 24) 147; Standing Committee on Legal Education and Training (n 24) 16.

51 Marsh and Ramsden (n 24) 147; Standing Committee on Legal Education and Training (n 24) 16.

52 Marsh and Ramsden (n 24) 148.

53 Marsh and Ramsden (n 24) 148; R Redmond and C Roper, (Steering Committee on the Review of Legal Education and Training in Hong Kong) "Legal Education and Training in Hong Kong: Preliminary Review - Report of the Consultants" (August 2001) $24<$ http:// www.hklawsoc.org.hk/pub_e/news/societyupdates/20010813a.asp> accessed 31 March 2020

54 Marsh and Ramsden (n 24) 148.

55 Marsh and Ramsden (n 24) 148.

56 Marsh and Ramsden (n 24) 148; Standing Committee on Legal Education and Training (n 24) 17.

57 Marsh and Ramsden (n 24) 149. 
rigour of the Bar Final Examination of the English Bar, was subsequently developed and inaugurated in 1972, in the Department of Law of the University of Hong Kong, rather than a separate body controlled by the legal profession. ${ }^{58}$ This development was (and is) markedly different from the position in England and Wales where the English Law Society's Final Examination (Part II) was replaced in 1993 with the one-year professional education programme - the Legal Practice Course (LPC) - for admission to practice law as a solicitor in England and Wales, and the erstwhile Bar Final Examination (Part II) of the English Bar Association was replaced with the one-year professional education programme - the Bar Vocational Course (BVC), now Bar Professional Training Course (BPTC) - in 1989. ${ }^{59}$ In Hong Kong, the PCLL was and remains to date the only requisite (one-year) professional education programme for candidates to proceed to pupillage or clerkship as the final step towards admission as either a barrister or a solicitor in Hong Kong. The PCLL is administered and offered by the universities, with substantive input and oversight by the professions. ${ }^{60}$

While local legal education and training was therefore firmly established and provided for by the turn of the century, preparations were underway, in terms of the Sino-British Joint Declaration (1984), for Hong Kong to be retroceded to the People's Republic of China as a Special Administrative Region under the one country two systems principle. Legal education in Hong Kong thus entered a new era of development in preparing students to practice law in post-handover Hong Kong, and the government was primarily concerned about supply:

From the perspective of commerce, a scarce supply of barristers and solicitors in private practice could have a substantial negative impact on Hong Kong's ability to sustain and expand its status as a finance centre. From a public law perspective, the government and judiciary still relied heavily on expatriate

58 Marsh and Ramsden (n 24) 149; also see Stephen Nathanson, Wilson WS Chow and Felix WH Chan "The University of Hong Kong's New PCLL" (2002) 32(2) Hong Kong Law Journal 381-400.

59 The Bar Vocational Course is now referred to as the Bar Professional Training Course (BPTC) and the pupillage period previously described in this article has since been reduced to a one-year term. Andrew Boon and Julian Webb, "Legal Education and Training in England and Wales: Back to the Future?" (March 2008) 58(1) Journal of Legal Education 79, 81; Mary C. Szto, "Towards a Global Bar: A look at China, Germany, England, and the United States" (2004) 14(3) Indiana International and Comparative Law Review 585, 599.

60 Marsh and Ramsden (n 24) 149; Chan (n 23) 3. For admission to practice law as a solicitor, candidates must also pass an additional examination in Accounts set by the Hong Kong Law Society. 


\section{LEGAL EDUCATION AND THE REPRODUCTION OF HIERARCHY:}

A CONTEMPORARY ASIAN READING OF A SEMINAL TEXT

legal expertise and feared an exodus in the legal profession as 1997 approached. From an equality perspective, the low lawyer-to-population ration - about 34 lawyers per 100,000 residents ( 0.03 per cent) - was complicating the principle of equal protection, inflating the cost of private sector legal services beyond the means of a majority of the population. Lastly, from an education perspective, there was a need to attract legal talent to the field of teaching and research, in order to educate successive generations of the legal profession. ${ }^{61}$

To address these concerns, the Department of Law of the University of Hong Kong not only increased its quotas for admission to the LLB and PCLL programmes (1987), but Hong Kong's newest tertiary institution at that time, the City Polytechnic of Hong Kong established in 1984 and rebranded in 1994 as the City University of Hong Kong, was granted permission by the University and Polytechnic Grants Commission (UPGC, formerly the University Grants Council (UGC)), to establish a Department of Law (1987), to develop another three-year LLB degree programme, and to enrol its first LLB students in the 1988 academic year. ${ }^{62}$ The establishment of a second law curriculum at another Hong Kong tertiary education institution was ultimately viewed as the only viable option for meeting the immediate and future needs of the local legal profession and ensuring the continued existence and development of the common law legal system that had been transplanted to, and was to remain in, the territory under the one country to systems principle. This addition and development seemingly achieved the desired result, and the legal system of and legal education and practice in Hong Kong subsequently developed in its own right.

The law curriculum originally developed by the Department of Law of the University of Hong Kong comprised mandatory law subjects undertaken in the first two years of study, with the final year mostly open for students to choose elective courses.

In the first year, students were introduced to the Legal System in Hong Kong, Legal Method and Reasoning, as well as the Law of Contract, the Law of Property and Constitutional Law. The second year consisted of additional core courses, including Criminal Law, the Law of Evidence, Tort and additional coursework in the Law of Property, as well as requiring students to write a dissertation on a legal topic of their choice. During their final year, students enrolled in one compulsory course - Jurisprudence - as well as four optional

${ }_{61}$ Marsh and Ramsden (n 24) 150.

${ }^{62}$ Marsh and Ramsden (n 24) 150; Standing Committee on Legal Education and Training (n 24) 17; Redmond and Roper (n 53) 24. 
subjects, choices of which included Administration of Trusts and Estates, Mercantile Law, Business Association, Family Law and Conflict of Law. In addition to coursework and dissertation requirements, students were required to participate in a moot programme, intended to better prepare them for the rigours of oral argument in a court of law. ${ }^{63}$

The law curriculum developed by the Department of Law of the City Polytechnic of Hong Kong - later City University of Hong Kong - was aimed at promoting an understanding of the law that fits into the society which it serves. To this end, the curriculum required:

1. a strong core of traditional common law subjects, with a focus on those areas of law most relevant to Hong Kong's future needs in both the public and private spheres;

2. substantial attention on the PRC's legal system, as it was Hong Kong's future sovereign;

3. consideration of the problems of operating a bilingual legal system, and how to reconcile those problems in such a way as not to compromise Hong Kong's common law tradition;

4. awareness for the importance of developing practical legal skills in tandem with legal knowledge. ${ }^{64}$

These original local Hong Kong law curricula were further extended in the 2004/5 academic year, based on the recommendations put forward in the so-called Redmond-Roper Report. ${ }^{65}$ The Redmond-Roper Report came about as part of the first comprehensive and independent review of legal education and training in Hong Kong, launched in November 1999, on recommendation of the Advisory Committee on Legal Education and its ad hoc Advisory Steering Committee on the Review of Legal Education and Training in Hong Kong established specifically for this purpose.$^{66}$ As a first stage to this comprehensive review process, a consultancy comprising two independent overseas education specialists, Paul Redmond, the dean of the Faculty of Law at the University of New South Wales, Australia, and Christopher Roper, the inaugural director of the Centre for Legal Education,

\footnotetext{
63 Marsh and Ramsden (n 24) 148.

64 Marsh and Ramsden (n 24) 150-151.

65 Redmond and Roper (n 53).

66 Marsh and Ramsden (n 24) 152; Luke Marsh and Michael Ramsden, "Fostering Civic Engagement in Legal Education: Observations from Hong Kong" (2014) 1(1) Asian Journal of Legal Education 57, 59; Redmond and Roper (n 53).
} 


\section{LEGAL EDUCATION AND THE REPRODUCTION OF HIERARCHY: A CONTEMPORARY ASIAN READING OF A SEMINAL TEXT}

Australia, was tasked to assess Hong Kong's legal education system. Their findings were published in August 2001. The second stage of this comprehensive review entailed the further evaluation of the consultancy report and Hong Kong's legal education system by the ad hoc Advisory Steering Committee. ${ }^{67}$

A key recommendation of the Redmond-Roper Report that was subsequently adopted was that the full-time, three-year LLB degree programme (honours) and law curriculum be extended to a four-year undergraduate LLB degree programme to provide for more non-law courses as part of the law curriculum, including subjects on liberal education. ${ }^{68}$ This recommendation was based on the observation by Redmond and Roper that the two tertiary education institutions providing legal education and training in Hong Kong at that time had failed "to meet the unique needs of Hong Kong's society and [that there was] a need to prepare graduates to meet the challenges of Hong Kong's legal system under PRC sovereignty". ${ }^{69}$ To this end, the Redmond-Roper report "sought to underscore the need of legal education to integrate theory with practice, contribute towards a broader liberal education and promote professional and ethical responsibility in a particular societal context". ${ }^{70}$ In the same year that the Hong Kong law curriculum was extended to a four-year undergraduate LLB degree (2004/5), the Chinese University of Hong Kong announced that the University Grants Council (now again known by its original designation) had accepted its proposal to establish Hong Kong's third law school, with the first enrolment of LLB students set for the 2006/7 academic year. ${ }^{71}$ It was evident from the law curriculum proposed by this third service provider of legal education and training that the Redmond-Roper Report had considerable influence:

[The] CUHK [Chinese University of Hong Kong] cited the importance of meeting Hong Kong's growing demand of the legal expertise necessary to

${ }^{67}$ Marsh and Ramsden (n 24) 152.

68 It is interesting to note that the LLB degree in England and Wales remains a three-year degree qualification. Marsh and Ramsden (n 24) 153; Boon and Webb (n 59) 80.

69 Marsh and Ramsden (n 24) 153.

70 Marsh and Ramsden (n 24) 153; Goodstadt notes, however, that an official assumption on the part of the Hong Kong Government took root during that time, "that universities could absorb cuts in funding without jeopardizing their 'core activities and the quality of education', and [that] they were expected to underwrite the costs of [sic, rather by] adding a year to their first degree programmes". Goodstadt (n 16) 22; also see Hong Kong Education Bureau, Item for Finance Committee (FCR (2007-08)36, November 2007) <https://www.legco.gov.hk/yr07-08/english/fc/fc/papers/f07-36e.pdf> accessed 31 March 2020.

71 Marsh and Ramsden (n 24) 153-154; Standing Committee on Legal Education and Training (n 24) 18. 
maintain the city's competitive advantage - the rule of law. It wanted to provide its law students with legal training that would help them to adapt to evolving societal circumstances; work in a variety of legal and non-legal contexts, including the business, finance, government and non-profit sectors and broaden their perspectives to incorporate a wider global awareness, with a particular focus on mainland China and Greater Asia. ${ }^{72}$

At present, the School of Law of the City University of Hong Kong, the Faculty of Law of the Chinese University of Hong Kong and the Faculty of Law of the University of Hong Kong, each offer a four-year full-time LLB degree programme akin to the comparable basic (three-year) law degree of the United Kingdom. Students can enter this degree programme upon having completed the Hong Kong Diploma of Secondary Education (HKDSE) which is the local, final secondary school examination of the Hong Kong Special Administrative Region, or, having completed a similar school leaving certificate from abroad, including the International Baccalaureate (IB) or the English A-levels. In addition, the Faculty of Law of the University of Hong Kong offer four five-year mixed-degree programmes:

- Bachelor of Business Administration and Law (BBA (Law)) \& LLB degree,

- Bachelor of Social Sciences in Government and Laws degree (BSocSc (Govt \& Laws) \& LLB degree,

- Bachelor of Engineering in Civil Engineering (Law) (BEng (CivE-Law) \& LLB degree, and

- Bachelor of Arts and Bachelor of Laws (BA \& LLB).

These mixed-degree programmes allow students to first qualify with a Bachelor's degree in a discipline other than law, and upon successful completion of this first Bachelor degree that also covers some law courses, to undertake two more years of study to complete the LLB degree. ${ }^{73}$ Likewise, the Faculty of Law of the Chinese University of Hong Kong offers a five-year mixed-degree programme, the Bachelor of Business Administration and Juris Doctor programme (BBA-JD). ${ }^{74}$

72 Marsh and Ramsden (n 24) 154; also see The Chinese University of Hong Kong, The School of Law of the Chinese University of Hong Kong (LC Paper No. CB(2)1605/0405(02), 1-2 <http://www.legco.gov.hk/yr04-05/english/panels/ajls/papers/aj0523cb2-16052e.pdf $>$ accessed 31 March 2020.

73 Faculty of Law, University of Hong Kong <https://www.law.hku.hk/programmes/ overview.php> accessed 31 March 2020; Marsh and Ramsden (n 24) 156.

74 Faculty of Law, University of Hong Kong <http://admission.cuhk.edu.hk/programmes/ BAJDN.html> accessed 31 March 2020. 


\section{LEGAL EDUCATION AND THE REPRODUCTION OF HIERARCHY: A CONTEMPORARY ASIAN READING OF A SEMINAL TEXT}

This mixed-degree programme allows students to graduate with both a BBA and JD degree over a period of five years and on a structure similar to the four fiveyear mixed-degree programmes of the University of Hong Kong. Finally, to cater for the demand for lawyers who can practice in multiple jurisdictions, the University of Hong Kong established a joint legal education programme with the University of British Columbia (UBC) in 2009, providing for a joint LLB-JD programme allowing students to complete two degrees in two jurisdictions over a period of five years. ${ }^{75}$ Following suit, the Faculty of Law of the Chinese University of Hong Kong launched its LLB-JD programme with King's College London in 2018, students enrolled for this programme will study at King's College London in the first and second years of their study, and at the Chinese University of Hong Kong for their third and fourth years of study to complete two law degrees from two jurisdictions over a period of four years. ${ }^{76}$

In addition to the mixed and double degrees and undergraduate four-year LLB degree programmes, each of the three tertiary education institutions involved in legal education and training in Hong Kong offers a postgraduate two-year JD (Juris Doctor) programme; a graduate law programme for applicants holding a non-law bachelor degree or an undergraduate law degree from a non-common law jurisdiction. The first Juris Doctor degree was introduced by the School of Law of the City University of Hong Kong in 2004, with the other two universities following suit; the Faculty of Law of the Chinese University of Hong Kong has been offering a JD degree since its establishment in 2006, and the University of Hong Kong accepted its first students on a JD programme in September $2009 .{ }^{77}$ These graduate degree programmes are similar to the JD programme of the United States of America, which is the primary law degree qualification for entry into the legal profession of the various states of the United States of America. The introduction of a graduate programme in law in Hong Kong became necessary after the English Law Society's decision not to offer Part I and Part II of their overseas qualifying examinations after 1980. This decision effectively meant that aspiring solicitors with a non-law degree and unable to enrol for the four-year undergraduate LLB degree no longer had any alternative avenue available for passing the academic requirement to be eligible for admission to the PCLL. ${ }^{78}$ At least the introduction of the JD programme provided an alternative for non-law graduates to obtain the

\footnotetext{
75 Faculty of Law, University of Hong Kong <https://www.law.hku.hk/programmes/joint. php> accessed 31 March 2020.

76 Faculty of Law, University of Hong Kong <http://www.law.cuhk.edu.hk/en/study/llb_ jd_programme-overview.php> accessed 31 March 2020.

77 Standing Committee on Legal Education and Training (n 24).

78 Chan (n 23) 4-5.
} 
necessary academic credentials. Moreover, the Chinese University of Hong Kong offers its JD programme also on a part-time basis, allowing for students to complete the programme over a period of four years. ${ }^{79}$

The Postgraduate Certificate in Laws (PCLL) remains the ultimate gateway to the Hong Kong legal profession. It is a one-year full-time course providing professional legal training, offered by the three tertiary education institutions responsible for legal education and training in Hong Kong, but with substantial input and oversight from the Hong Kong Law Society and the Hong Kong Bar Association. It is only upon completion of the PCLL that candidates can proceed to pupillage or clerkship as the final step towards admission as barrister or solicitor, respectively. Richard Able observed as follows with regard to the impact of the comparable one-year compulsory vocational course on the English legal education system:

Professional education has restricted entry in two ways: by virtue of its cost and, more recently, through limitations on the number of places. ...Indeed, the number of places in the mandatory courses is itself becoming a limitation on entry to the profession. ${ }^{80}$

This is certainly also true of the situation in Hong Kong, as will be evident from the discussion below.

Given the nature and locality of the student observations and opinions collected for this article, its focus is exclusively on the reproduction of hierarchy in local legal education and practical training in the Hong Kong Special Administrative Region. The admission requirements for qualified solicitors and barristers holding foreign formal and professional credentials and wishing to practice law in Hong Kong will not be considered here. ${ }^{81}$ Note can, however, be taken of the PCLL Conversion Examination which was introduced in 2008. In the 2001

79 Faculty of Law, Chinese University of Hong Kong <http://www.law.cuhk.edu.hk/en/ study/jd_programme-overview.php> accessed 31 March 2020.

80 Abel (n 26) 146 and 148.

81 See the Overseas Lawyers (Qualification for Admission) Rules Cap 159Q, the Foreign Lawyers Registration Rules Cap 159S and the Barristers (Qualification for Admission and Pupillage) Rules Cap 159AC. The matter of local solicitors or barristers respectively wanting to switch over to the other profession - that is, a solicitor wishing to be admitted as a barrister or a barrister wishing to be admitted as a solicitor also falls beyond the scope of this article. For the relevant legislative provisions in this regard see the Barristers (Qualification for Admission and Pupillage) Rules Cap 159AC and the Trainee Solicitors Rules Cap 159J. 


\section{LEGAL EDUCATION AND THE REPRODUCTION OF HIERARCHY: A CONTEMPORARY ASIAN READING OF A SEMINAL TEXT}

Redmond-Roper report, it was recommended that an additional gateway to the legal profession of Hong Kong be established for candidates holding an academic qualification other than those offered by the three law schools/faculties in Hong Kong, by way of a "conversion course" through which such candidates can then, upon successful completion, seek admission to the PCLL. This recommendation was partly acceded to when the Standing Committee on Legal Education and Training in Hong Kong ${ }^{82}$ established the PCLL Conversion Examination in 2008, to be administered by the independent PCLL Conversion Examination and Administration Limited. ${ }^{83}$ This alternative gateway to the PCLL programme and ultimately also to practice law in Hong Kong as either a solicitor or a barrister requires of candidates to demonstrate competence in select subjects in order to qualify for PCLL admission. Marsh and Ramsden note that the establishment of the independent PCLL Conversion Examination and Administration Limited "has spawned its own subsidiary legal education market, one in which universities and commercial organisations provide preparatory courses for the exam". ${ }^{84}$ Of this alternative gateway to enter the legal profession of Hong Kong, one student remarked as follows:

Since 2008, a so-called 'self-protective' policy was launched stating that law graduates from other common law jurisdictions must also pass the "conversion examination'. There is even no exception for graduates form Cambridge or Oxford or other top universities from the UK. This policy ensures localization on one hand, however, it further strengthens the reproduction of hierarchy. (JD student, 2018)

The legislative provisions currently regulating the admission of aspiring solicitors and barristers to the legal profession are set out in the Legal Practitioners Ordinance Cap 159 (specifically sections 3, 4 and 27), as well as the subsidiary legislation to Cap 159, particularly the Admission and Registration Rules Cap 159B, Trainee Solicitors Rules Cap 159J (specifically section 7), the Barristers (Qualification) Rules Cap 159E, The Barristers (Admission) Rules Cap 159AA, Barristers (Advanced Legal Education Requirement) Rules Cap 159AB and the

\footnotetext{
82 The Standing Committee on Legal Education and Training (SCLET) was established in terms of s 74A of the Legal Practitioners Ordinance Cap 159 and "is empowered to keep under review legal education and training in Hong Kong, to make recommendations thereon, and to collect and disseminate information about legal education and training in Hong Kong". Standing Committee on Legal Education and Training (n 24) 24.

83 Marsh and Ramsden (n 24) 154.

84 Marsh and Ramsden (n 24) 154.
} 
Barristers (Qualification for Admission and Pupillage) Rules Cap 159AC (specifically section 4).

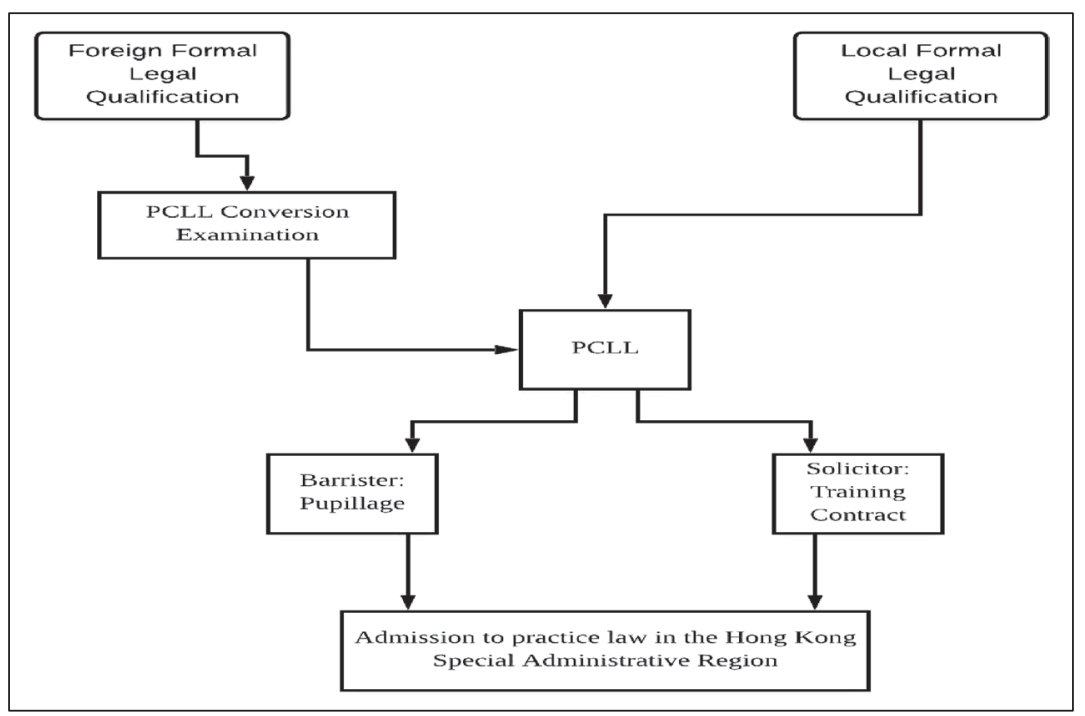

\section{LEGAL EDUCATION IN THE HONG KONG SPECIAL ADMINISTRATIVE REGION: REPRODUCING AND AUGMENTING COLONIAL HIERARCHIES IN LAW}

Part II of this article provided an overview of the legal education and training landscape of the Hong Kong Special Administrative Region, as well as its legal profession, from a legal-historical perspective to date. It was evident from this overview that the legal system and laws of the Hong Kong Special Administrative Region, as well as its legal education system, have been transplanted from England and Wales, the erstwhile colonial power of Hong Kong. This colonial heritage remains palpable in Hong Kong, despite extensive legal reform and development since the territory's retrocession on 1 July 1997 to the People's Republic of China. The discussion and analysis in this third part of the article now turn to the narratives of local Hong Kong law students, relating their experiences and perceptions about various aspects of legal education in Hong Kong.

\section{A. Law School Admission}

Admission to the various law degrees and programmes offered by the three higher education institutions endorsed to offer legal education and training in the Hong Kong Special Administrative region is highly competitive. For admission to any of 


\section{LEGAL EDUCATION AND THE REPRODUCTION OF HIERARCHY: A CONTEMPORARY ASIAN READING OF A SEMINAL TEXT}

the undergraduate LLB degrees, applicants who have completed an internationally recognised and rigorous final examination like the IB or A-levels are particularly sought after while only those with the highest results in the local Hong Kong Diploma of Secondary Education (HKDSE) stand a chance of being admitted. ${ }^{85}$ Of this, Hong Kong students remarked as follows:

...the hierarchy is stemmed from the earliest stage of the education system.... The hierarchy is beyond what Kennedy states as it has been rooted even at the pre-school level. (JD student, 2018)

In HK hierarchy even existed before you born. What hospital you born, what kindergarten and high school you went, internship etc. play a role for your future in law career. (JD student, 2016)

It is understandable parents want to give birth to clever child/children. The more clever the better. As you know, the competition in HK is so fierce. If you are not clever enough, how can you survive? How can you enjoy your life with good quality? (JD student, 2016)

Having excellent grades and a stellar final secondary school leaving certificate are therefore imperative to gaining admission to one of the three undergraduate law programmes in Hong Kong. However, "being clever" is indeed not enough as it is trite that a positive correlation generally exists between socio-economic status and academic performance. Middle class students, for example, usually have access to additional academic resources and support their parents and/or caregivers can afford or arrange for through their extensive networks.

Based on my educational experience in Hong Kong, parents of higher social class tend to be more educated and receive higher income. They are more resourceful in building education advantages to their children, for example, sending them to private schools, enriching their academic experience and cultivating their social network from a young age. In this way, it sharpens children's competitive edge and builds up eye-catching academic profile in their applications to law school. ...The underrepresentation of lower class students in law school ...[is] further [carried] forward to legal profession.

85 The admission scores of HKDSE applicants for the 2017/2018 academic year can be accessed online: City University of Hong Kong <http://www.cityu.edu.hk/admo/hkdse/ scores/jupas_scores2018.pdf> accessed 31 March 2020; Chinese University of Hong Kong < http://www.cuhk.edu.hk/adm/jupas/adm_scores2018.pdf> accessed 31 March 2020; University of Hong Kong <https://www.hku.hk/f/upload/18637/2018\%20 Admissions\%20Score.pdf $>$ accessed 31 March 2020. 
Students with no family or social networks often encounter great barriers in seeking internship and employment opportunities. The power of inherited advantage can be clearly demonstrated in my recent experience at a law firm a 17-year-old high school student without any legal knowledge was able to secure an internship opportunity at the most reputable chamber, largely due to the elite social networks of his family. At another level, legal education acts as a collaborator in worsening social inequality - by giving more affluent students better access to prestigious jobs, and in turn, higher salaries (JD student, 2019)

This much was acceded to by the Faculty of Law of the Chinese University of Hong Kong in its 2015 LLB annual report to the Standing Committee on Legal Education and Training in Hong Kong: 86

Although there has been some concern in the media about non-JUPAS students being from wealthier families who can afford to send their children to international schools or overseas for their education, many local schools now offer an international curriculum such as the International Baccalaureate (IB). The Faculty will continue to admit students primarily on the basis of academic ability and perceived aptitude for the study of law, though we also seek to ensure students from all backgrounds have the opportunity to join us. ${ }^{87}$

While the Chinese University of Hong Kong noted in its 2015 LLB annual report that it sought to ensure that students from all backgrounds have the opportunity to study law (at the Chinese University of Hong Kong), it remains unclear what the three tertiary education institutions involved in legal education and training in Hong Kong are currently doing to ensure some socio-economic diversity in its respective law student bodies. Hong Kong students noted, for example, that social and economic affluence (together with grades) ultimately remain the primary determinants for admission to a law degree programme in Hong Kong:

On the face of education, people earn higher grades by talent, diligence, horizon and the way of thinking. However, in fact, those factors are mostly

\footnotetext{
86 The Standing Committee on Legal Education and Training is a statutory body established in 2004 based on the recommendations made by the Redmond-Roper Report, and it replaced the Advisory Committee on Legal Education referred to earlier in this article. Marsh and Ramsden (n 24) 153.

87 Faculty of Law, The Chinese University of Hong Kong, Report on the LLB Programme in the Standing Committee on Legal Education and Training Annual Report, (2015) 25 <https://www.sclet.gov.hk/eng/pdf/2015e.pdf> accessed 31 March 2020.
} 


\section{LEGAL EDUCATION AND THE REPRODUCTION OF HIERARCHY:}

A CONTEMPORARY ASIAN READING OF A SEMINAL TEXT

granted by their families. Under the fairness mask, the hierarchy already exists on the beginning of education. (LLM student, 2019)

Family status basically determines the future or at least, the starting point of a law student. For example, a student who comes from a relatively wealthier family can easily get internships from law firms due to connections and have much more opportunities to study overseas to get more certificates and experience. These students stand in a high standing point which they can easily foresee their success in legal career. (JD student, 2016)

There is a financial cost, a cost that yells out upper-middle class, second or third generation Hong Kong resident, typically residing on Hong Kong Island or in Kowloon, but seldom further beyond these enclaves. Yet, hard work alone is attributed to the high-achiever's "success" in the minds of the envious. Kennedy is not wrong in hypothesising that there are deep socio-economic inequalities inherent unto the word lawyer. (JD student, 2016)

The impact of affluence on law school admission processes is particularly evident in the JD programmes, as this formal legal qualification is decidedly more expensive than the undergraduate LLB degrees. In 2019, the tuition fees for a JD programme was approximately $\mathrm{HK} \$ 388,080$ at the City University of Hong Kong, ${ }^{88}$ HK\$403,200 at the Chinese University of Hong Kong ${ }^{89}$ and HK\$400,000 at the University of Hong Kong..$^{90}$ This stand in stark contrast to the four-year undergraduate LLB degrees which form part of a selection of full-time bachelor degree programmes funded by the Government of the Hong Kong Special Administrative Region. The University Grants Committee (UGC) of Hong Kong not only coordinates government funding to the eight public tertiary education institutions in the Hong Kong Special Administrative Region, ${ }^{91}$ it also coordinates the approximately 15,000 fully funded first-year-first-degree places available in

$88 \mathrm{HK} \$ 5,390$ x 72 credits <https://wikisites.cityu.edu.hk/sites/tuitionfee/prog/sf_P43. htm> accessed 31 March 2020.

89 HK\$5,600 x 72 units <https://www.gs.cuhk.edu.hk/admissions/programme/law\#jurisdoctor> accessed 31 March 2020.

90 Faculty of Law, University of Hong Kong <http://www.law.hku.hk/postgrad/ jurisdoctor/tuition-fee/> accessed 31 March 2020.

91 These are the City University of Hong Kong (CityU), Hong Kong Baptist University (HKBU), Lingnan University (LingnanU), the Chinese University of Hong Kong (CUHK), the Education University of Hong Kong (EdUHK), the Hong Kong Polytechnic University (PolyU), the Hong Kong University of Science and Technology (HKUST) and the University of Hong Kong (HKU). University Grants Committee <https://www.jupas.edu. hk/en/about-jupas/introduction/> accessed 31 March 2020. 
selected full-time bachelor degree programmes offered by these institutions. The three four-year full-time LLB degree programmes of the City University of Hong Kong, the Chinese University of Hong Kong and the University of Hong Kong are part of this Joint University Programmes Admissions System (JUPAS) and every year secondary school leavers with qualifying Hong Kong Diploma of Secondary Education (HKDSE) results may apply through the JUPAS system for a place in one of the LLB degree programmes. A student who has secured a JUPAS place in one of the government funded first-degree full-time bachelor's degrees receive a full tuition waiver. ${ }^{92}$

Especially for Juris Doctor students, the tuition itself serves as a first layer of filter. The unrealistically high cost deters individuals whose family are financially incapable of supporting them. The second filter comes into play at the start of law school, when unprivileged students begin finding themselves struggling academically and particularly in English. Some individuals drop out as they realise that their locally learned language skills are not sufficient in helping them survive law school. In Hong Kong, people's language skills are highly related to their social status. It is unsurprising to see that the lower social class students have almost no access to English learning, while the topic social class emerges in a bilingual environment. It all traces back to the deep rooted hierarchy within the entire education system. (JD student February 2019)

For instance, City University's own JD programme costs upwards of $\$ 388,080$ (City University of Hong Kong, 2018) just for tuition alone, which is 23 times the individual median monthly wage (\$16 800) (Census and Statistics Department, 2017), in a city where no reliable social security exists, and one is expected to financially support his parents upon finding a job. This is compounded by the self-financed nature of the JD programme, which saddles a student with a huge financial burden and deters those from the working class from even considering law school as an option... (JD student, 2019)

While most of the LLB students are therefore spared the financial brunt of having to pay tuition fees, all students must, upon completion of their first law degree, complete the PCLL programme. The Hong Kong Government by way of its University Grants Committee also fund a limited number of places in each of the PCLL programmes of the three tertiary education institutions responsible for

92 Government of the Hong Kong Special Administrative Region, Education Bureau $<$ https://www.edb.gov.hk/en/edu-system/postsecondary/local-higher-edu/publiclyfunded-programmmes/index.html> accessed 31 March 2020. 


\section{LEGAL EDUCATION AND THE REPRODUCTION OF HIERARCHY:}

A CONTEMPORARY ASIAN READING OF A SEMINAL TEXT

legal education and training in Hong Kong. Students who are able to secure a government funded place in a PCLL programme and who hold an LLB or JD degree from a local institution have to pay a tuition fee of $\mathrm{HK} \$ 42,100$. And students who have secured a government funded place in a PCLL programme but who completed their formal legal qualification elsewhere must pay a tuition fee of HK\$140,000 at the City University of Hong Kong, HK\$145, 000 at the Chinese University of Hong Kong and HK\$161,000 at the University of Hong Kong. For self-financed PCLL students, that is students who were unable to secure a government funded place, the tuition fees are as follows: HK\$187,920 at the City University of Hong Kong, HK\$174,500 at the University of Hong Kong and HK $\$ 184,500$ at the Chinese University of Hong Kong. ${ }^{93}$ Of these three tertiary education institutions only the University of Hong Kong offers a part-time PCLL programme the tuition fee of which is $\mathrm{HK} \$ 203,500 .{ }^{94}$ It is therefore undoubtedly that admission to the various law degree programmes in Hong Kong favours wealthy or middle class applicants.

...legal education is an act of monetary game for the wealthy and it strengthens the continuation of the social hierarchy. (JD student, 2018)

The great expense with which legal studies in Hong Kong is currently associated is particularly ironic given the original aim for establishing local legal education in the Special Administrative Region; to curb the expense and extravagant cost of sending the best students to the United Kingdom for their education and training.

The admission statistics for the various LLB and JD programmes offered in the Hong Kong Special Administrative Region are reported annually by the three tertiary education institutions responsible for legal education and training, to the Standing Committee on Legal Education and Training in Hong Kong. ${ }^{95}$ The Standing Committee on Legal Education and Training is established under section 74A of the Legal Practitioners Ordinance Cap 159, and is tasked, inter alia, with broad review,

${ }^{93}$ Faculty of Law, Chinese University of Hong Kong <https://www.gs.cuhk.edu.hk/ admissions/programme/law\#postgraduate-certificate-in-laws> accessed 31 March 2020; Faculty of Law, University of Hong Kong <https://www.ple.hku.hk> accessed 31 March 2020; School of Law, City University of Hong Kong <https://www.cityu.edu.hk/slw/ PCLL/admission.html> accessed 31 March 2020.

${ }^{94}$ Faculty of Law, University of Hong Kong <https://www.ple.hku.hk> accessed 31 March 2020.

${ }^{95}$ The annual reports are available online at <https://www.sclet.gov.hk/eng/pub.htm> accessed 31 March 2020. 
evaluation and assessment powers over "the system and provision of legal education and training in Hong Kong", including the academic requirements and standards for admission to the Postgraduate Certificate in Laws programme, as well as any vocational training of prospective legal practitioners in Hong Kong by organisations other than the Society or the Hong Kong Bar Association..$^{96}$ The Committee consists of 17 members appointed by the Chief Executive of the Hong Kong Special Administrative Region, all of whom are nominated by the various stakeholders to legal education and practice in Hong Kong, including the Chief Justice of the Hong Kong Court of Final Appeal (2 nominations), the Secretary for Justice (1 nomination), the Secretary for Education (1 nomination), the Hong Kong Law Society (2 nominations), the Hong Kong Bar Association (2 nominations), the Vice-Chancellors and/or President of the three universities offering law degrees ( 2 nominations each, 6 in total), the public (2 nominations), and one person nominated by the Federation for Self-financing Tertiary Education, a non-profit-making educational organisation which provide continuing legal education courses in Hong Kong. ${ }^{97}$

\begin{tabular}{|c|c|c|c|c|}
\hline \multicolumn{5}{|c|}{$\begin{array}{l}\text { DATA FROM THE ANNUAL REPORTS OF THE STANDING COMMITTEE ON } \\
\text { LEGAL EDUCATION AND TRAINING IN HONG KONG }\end{array}$} \\
\hline & & $\begin{array}{l}\text { City University } \\
\text { of Hong Kong }\end{array}$ & $\begin{array}{l}\text { Chinese } \\
\text { University of } \\
\text { Hong Kong }\end{array}$ & $\begin{array}{l}\text { University of Hong } \\
\text { Kong }\end{array}$ \\
\hline \multicolumn{5}{|c|}{$2015 / 2016$} \\
\hline & $\begin{array}{l}\text { Applications } \\
\text { received }\end{array}$ & 704 & Unknown & Unknown \\
\hline LLB & $\begin{array}{l}\text { Students } \\
\text { admitted }\end{array}$ & $\begin{array}{l}55 \\
25 \text { JUPAS and } \\
24 \text { non-JUPAS } \\
\text { students; } 5 \\
\text { Mainland } \\
\text { students and } 1 \\
\text { student from } \\
\text { another } \\
\text { jurisdiction }\end{array}$ & $\begin{array}{l}75 \\
43 \text { JUPAS and } \\
30 \text { non-JUPAS } \\
\text { students; } 2 \\
\text { Mainland } \\
\text { students }\end{array}$ & $\begin{array}{l}256 \\
\text { LLB: } 98 \text { students } \\
69 \text { JUPAS and } 23 \\
\text { non-JUPAS students; } 5 \\
\text { Mainland students and } 1 \\
\text { "through internal transfer" } \\
\text { Mixed-degree } \\
\text { programmes: } 158 \\
\text { students } \\
\text { BBA (Law) \& LLB: } 64 \\
\text { students; BSocSc (Govt \& } \\
\text { Laws) \& LLB: } 65 \text { students; } \\
\text { BA (Literary Studies) \& } \\
\text { LLB: } 29 \text { students }\end{array}$ \\
\hline
\end{tabular}

96 Section 74A(2)(a)-(d) of the Legal Practitioners Ordinance Cap 159.

97 Section 74A(3)(a)(i)-(ix) of the Legal Practitioners Ordinance Cap 159. 
LEGAL EDUCATION AND THE REPRODUCTION OF HIERARCHY: A CONTEMPORARY ASIAN READING OF A SEMINAL TEXT

\begin{tabular}{|c|c|c|c|c|}
\hline & & $\begin{array}{l}\text { City University } \\
\text { of Hong Kong }\end{array}$ & $\begin{array}{l}\text { Chinese } \\
\text { University of } \\
\text { Hong Kong }\end{array}$ & $\begin{array}{l}\text { University of Hong } \\
\text { Kong }\end{array}$ \\
\hline חת & $\begin{array}{l}\text { Applications } \\
\text { received }\end{array}$ & 341 & $\begin{array}{l}946 \\
\text { Full-time: } 601 \\
\text { Part-time: } 345\end{array}$ & 350 plus \\
\hline JD & $\begin{array}{l}\text { Students } \\
\text { admitted }\end{array}$ & 82 & $\begin{array}{l}196 \\
\text { Full-time: } 130 \\
\text { Part-time: } 66\end{array}$ & 34 \\
\hline & & & $6 / 2017$ & \\
\hline & $\begin{array}{l}\text { Applications } \\
\text { received }\end{array}$ & 709 & Unknown & Unknown \\
\hline LLB & $\begin{array}{l}\text { Students } \\
\text { admitted }\end{array}$ & $\begin{array}{l}62 \\
42 \text { JUPAS and } \\
16 \text { non-JUPAS } \\
\text { students; } 4 \\
\text { Mainland } \\
\text { students }\end{array}$ & $\begin{array}{l}108 \\
49 \text { JUPAS and } \\
55 \text { non-JUPAS } \\
\text { students; } 4 \\
\text { Mainland } \\
\text { students }\end{array}$ & $\begin{array}{l}253 \\
\text { LLB: } 95 \text { students } \\
72 \text { JUPAS and } 18 \\
\text { non-JUPAS students; } \\
4 \text { Mainland students and } \\
1 \text { "through internal } \\
\text { transfer" } \\
\text { Mixed-degree } \\
\text { programmes: } 158 \\
\text { students } \\
\text { BBA (Law) \& LLB: } 83 \\
\text { students; BSocSc (Govt \& } \\
\text { Laws) \& LLB: } 47 \text { students; } \\
\text { BA (Literary Studies) \& } \\
\text { LLB: } 27 \text { students }\end{array}$ \\
\hline n & $\begin{array}{l}\text { Applications } \\
\text { received }\end{array}$ & 315 & $\begin{array}{l}743 \\
\text { Full-time: } 473 \\
\text { Part-time: } 270\end{array}$ & 260 plus \\
\hline J & $\begin{array}{l}\text { Students } \\
\text { admitted }\end{array}$ & 101 & $\begin{array}{l}195 \\
\text { Full-time: } 130 \\
\text { Part-time: } 65\end{array}$ & 44 \\
\hline
\end{tabular}


THE DENNING LAW JOURNAL

\begin{tabular}{|c|c|c|c|c|}
\hline & & $\begin{array}{l}\text { City University } \\
\text { of Hong Kong }\end{array}$ & $\begin{array}{l}\text { Chinese } \\
\text { University of } \\
\text { Hong Kong }\end{array}$ & $\begin{array}{l}\text { University of Hong } \\
\text { Kong }\end{array}$ \\
\hline & & & $7 / 2018$ & \\
\hline & $\begin{array}{l}\text { Applications } \\
\text { received }\end{array}$ & 620 & Unknown & Unknown \\
\hline LLB & $\begin{array}{l}\text { Students } \\
\text { admitted }\end{array}$ & $\begin{array}{l}66 \\
43 \text { JUPAS and } \\
17 \text { non-JUPAS } \\
\text { students; } 6 \\
\text { Mainland } \\
\text { students }\end{array}$ & $\begin{array}{l}80 \\
45 \text { JUPAS and } \\
29 \text { non-JUPAS } \\
\text { students; } 6 \\
\text { Mainland }\end{array}$ & $\begin{array}{l}243 \\
\text { LLB: } 99 \text { students } \\
66 \text { JUPAS and } 26 \\
\text { non-JUPAS students; } \\
7 \text { Mainland students } \\
\text { Mixed-degree } \\
\text { programmes: } 144 \\
\text { students } \\
\text { BBA (Law) \& LLB: } 67 \\
\text { students; BSocSc (Govt \& } \\
\text { Laws) \& LLB: } 50 \text { students; } \\
\text { BA (Literary Studies) \& } \\
\text { LLB: } 27 \text { students }\end{array}$ \\
\hline & $\begin{array}{l}\text { Applications } \\
\text { received }\end{array}$ & 322 & $\begin{array}{l}753 \\
\text { Full-time: } 460 \\
\text { Part-time: } 293\end{array}$ & 270 plus \\
\hline & $\begin{array}{l}\text { Students } \\
\text { admitted }\end{array}$ & 104 & $\begin{array}{l}205 \\
\text { Full-time: } 130 \\
\text { Part-time: } 75\end{array}$ & 47 \\
\hline
\end{tabular}

It is evident from this data that admission to the various LLB and JD programmes offered in Hong Kong is indeed a competitive affair. While seemingly only 10 per cent of applicants to the LLB degree programmes are successful in securing a place, JD applicants have between a 20 and 30 per cent chance of gaining admission to the graduate law degree programme, albeit, at a considerable cost. Moreover, with admission being so exclusively based on academic merit and so obliquely favouring the affluent, legal education in the Special Administrative Region of Hong Kong is indeed for the elite.

By taking only the brightest students, the institutions are creating a narrow and exclusive pool of 'excellence'. By glorifying certain occupations such as medicine, law, and business, the Hong Kong education system perpetuates the 


\section{LEGAL EDUCATION AND THE REPRODUCTION OF HIERARCHY:}

A CONTEMPORARY ASIAN READING OF A SEMINAL TEXT

twisted mindset that studying these subjects at university is the sole path to success. ...this rigid hierarchy is merely a byproduct of the elite culture in Hong Kong. (JD student 2019)

Thus, without the Hong Kong Government and the respective universities taking class inequality seriously, and implementing policies such as affirmative action or need-based financial aid on a consistent and transparent basis, the existing legal hierarchies will continue to reinforce class inequality in Hong Kong.

...it was until the first class did I realise that how easy things are to those come with background and how life is a struggle to those come rather unimpressively. As soon as we were settled for class, my classmates were extensively sharing their background. The guy on the left with Hermes from top to toes revealed his residency in Residence Bel-Air. Girl on the right with no prior legal academic background earnestly shares her work experience in Magic Circle. A classmate at the front introduces us to his alma maters, schools exclusively for affluent upper-class. With a relatively less attractive background, I was left in my seat, unsettled and shock. I wondered if there was any place for me. (JD student 2019)

\section{B. Training for the Hierarchy: The PCLL Programme}

The exclusive importance of excellent grades for gaining admission to the LLB or JD programmes of the three higher education institutions responsible for legal education and training in Hong Kong also continues once students are at university. As explained earlier, the Postgraduate Certificate in Laws (PCLL) programme was inaugurated in 1972 and serves as the fundamental entry requirement to practice law in Hong Kong. It is only once students have successfully completed the PCLL that they are allowed to proceed with the requisite practical training in the form of a pupillage or training contract to ultimately practice law as either a barrister or a solicitor in Hong Kong. Admission to the PCLL is highly competitive at all three the tertiary education institutions and it is also, similar to the admission requirements for the LLB and JD programmes, exclusively based on academic excellence.

First of all, since there is no bar exam in HK, the only way for people to be a lawyer is to get the Postgraduate Certificate in Laws (PCLL). In other words, GPA becomes the most important thing for law school students to get into legal profession in HK. Under a strictly divided ranking in law school, students 
have to focus on how to get a high GPA rather than justice itself. (JD student, 2019)

Such strict control of PCLL makes legal education costly; a law student may spend lots of time and money before he or she become a lawyer. A student from middle-lower class would hesitate to choose law when considering the expense, which results in law schools more likely to recruit middle-upper class students and new lawyers may more likely come from middle-upper class. When these lawyers at last become the maker of the rules, hierarchy of the whole system would be strengthened not weakened, the admission of lawyer remains close and legal education which serve such system would remain unchanged. (JD student, 2018)

The PCLL is the only thing and everyday topics among students. We had been told that if we can't get in to the PCLL, our life is over. HK law student are like gladiators fighting each other to get in to the PCLL. (JD student, 2016)

Regard can be had to the annual reports of the Standing Committee on Legal Education and Training in Hong Kong for empirical data on the competitive admission processes of the PCLL programmes. ${ }^{98}$ Although statistically, it must be noted that admission to the PCLL programmes is less competitive than those of the LLB and JD programmes discussed in the preceding part of this article.

\begin{tabular}{|c|c|c|c|c|}
\hline \multicolumn{5}{|c|}{$\begin{array}{l}\text { DATA FROM THE ANNUAL REPORTS OF THE STANDING COMMITTEE ON } \\
\text { LEGAL EDUCATION AND TRAINING IN HONG KONG }\end{array}$} \\
\hline & & $\begin{array}{l}\text { City University } \\
\text { of Hong Kong }\end{array}$ & $\begin{array}{l}\text { Chinese } \\
\text { University of } \\
\text { Hong Kong }\end{array}$ & $\begin{array}{l}\text { University of Hong } \\
\text { Kong }\end{array}$ \\
\hline \multicolumn{5}{|c|}{$2015 / 2016$} \\
\hline & $\begin{array}{l}\text { Applications } \\
\text { received }\end{array}$ & 502 & 303 & 717 \\
\hline PCLL & $\begin{array}{l}\text { Students } \\
\text { admitted }\end{array}$ & $\begin{array}{l}171 \text { (of } 188 \text { offers } \\
\text { made) } \\
53 \% \text { comprised } \\
\text { CityU graduates } \\
\text { and } 47 \% \\
\text { graduates from } \\
\text { other institutions }\end{array}$ & $\begin{array}{l}150 \\
129 \text { students held } \\
\text { local law } \\
\text { qualifications and } \\
21 \text { held non-local } \\
\text { law qualifications }\end{array}$ & $\begin{array}{l}340 \\
\text { Full-time: } 260 \\
\text { Part-time: } 80 \\
\text { Most of these places } \\
\text { went to HKU } \\
\text { graduates, with UK } \\
\text { graduates having the } \\
\text { second largest share. }\end{array}$ \\
\hline
\end{tabular}

98 The annual reports are available online at $<$ https://www.sclet.gov.hk/eng/pub.htm> accessed 31 March 2020. 
LEGAL EDUCATION AND THE REPRODUCTION OF HIERARCHY: A CONTEMPORARY ASIAN READING OF A SEMINAL TEXT

\begin{tabular}{|c|c|c|c|c|}
\hline & & $\begin{array}{l}\text { City University } \\
\text { of Hong Kong }\end{array}$ & $\begin{array}{l}\text { Chinese } \\
\text { University of } \\
\text { Hong Kong }\end{array}$ & $\begin{array}{l}\text { University of Hong } \\
\text { Kong }\end{array}$ \\
\hline \multicolumn{5}{|c|}{$2016 / 2017$} \\
\hline \multirow[b]{2}{*}{ PCLL } & $\begin{array}{l}\text { Applications } \\
\text { received }\end{array}$ & 470 & 332 & 706 \\
\hline & $\begin{array}{l}\text { Students } \\
\text { admitted }\end{array}$ & $\begin{array}{l}209 \text { (of } 231 \\
\text { offers made) } \\
49 \% \text { comprised } \\
\text { CityU graduates } \\
\text { and } 51 \% \\
\text { graduates from } \\
\text { other institutions }\end{array}$ & $\begin{array}{l}177 \\
149 \text { students held } \\
\text { local law } \\
\text { qualifications and } \\
28 \text { held non-local } \\
\text { law qualifications }\end{array}$ & $\begin{array}{l}397 \\
\text { Full-time: } 307 \\
\text { Part-time: } 90 \\
\text { Most of these places } \\
\text { went to HKU } \\
\text { graduates, with UK } \\
\text { graduates having the } \\
\text { second largest share. }\end{array}$ \\
\hline \multicolumn{5}{|c|}{$2017 / 2018$} \\
\hline \multirow[b]{2}{*}{ PCLL } & $\begin{array}{l}\text { Applications } \\
\text { received }\end{array}$ & 485 & 306 & 717 \\
\hline & $\begin{array}{l}\text { Students } \\
\text { admitted }\end{array}$ & $\begin{array}{l}201 \text { (of } 248 \\
\text { offers were } \\
\text { made) } \\
43 \% \text { comprised } \\
\text { local graduates } \\
\text { and } 57 \% \\
\text { comprised } \\
\text { graduates from } \\
\text { overseas } \\
\text { institutions }\end{array}$ & $\begin{array}{l}165 \text { (of } 174 \text { offers } \\
\text { were made) }\end{array}$ & $\begin{array}{l}417 \\
\text { Full-time: } 325 \\
\text { Part-time: } 92 \\
\text { Most of these places } \\
\text { went to HKU } \\
\text { graduates, with UK } \\
\text { graduates having the } \\
\text { second largest share. }\end{array}$ \\
\hline
\end{tabular}

Already by 1998, with two Hong Kong higher education institutions - the University of Hong Kong and the City University of Hong Kong - offering the PCLL programme, the legal profession expressed the need to have its fundamental entry requirement, the PCLL, standardised. ${ }^{99}$ The Advisory Committee on Legal Education consequently established a sub-committee (in 1998) comprising representatives of the two universities, alongside representatives from The Law Society of Hong Kong, the Hong Kong Bar Association and the judiciary, to explore the implementation of a common examination system for Hong Kong's PCLL. ${ }^{100}$ The idea was therefore for the two universities to continue offering the PCLL programme, but for all PCLL candidates to write a final, common entrance

99 Marsh and Ramsden (n 24) 151.

100 Marsh and Ramsden (n 24) 151. 
examination for entry to the legal profession. Whilst members of the Hong Kong Law Society and the Hong Kong Bar Association unanimously supported the proposal, the two universities opposed. ${ }^{101}$ Curiously, the argument put forward by the University of Hong Kong and the City University of Hong Kong, "that the PCLL curricula were not well suited to common examinations which require that a common course of study be designed first", also confirmed the general concern of the Hong Kong legal profession "that the absence of standardisation in legal education did not ensure that graduates from the two schools were equally prepared for their careers, and that the quality of new entrants to the profession was inadequate". ${ }^{102}$ Facing a stark standoff and divide between the Hong Kong legal academia on the one side and the legal professionals on the other, the Advisory Committee on Legal Education decided in July 1999 to suspend the push for a common PCLL examination, pending a thorough review of the general state of legal education in Hong Kong. ${ }^{103}$

In the Redmond-Roper report published in August 2001 and referred to earlier in this article, the PCLL programme again came under scrutiny as the two consultants submitted that the curricula offered by the two universities were insufficient and designed as extensions to the law degree, focusing "predominantly on academic pursuits at the expense of skills development and practical training". ${ }^{104}$ Different, however, from the proposal by the Hong Kong legal fraternity to introduce a common entrance examination as an additional hurdle or obstacle on the road to the coveted status legal professional in Hong Kong, Redmond and Roper recommended that the PCLL be replaced by a 16-week legal practice course administered by an institution independent from the universities offering legal education and training at that time..$^{105}$ Yet, the Advisory Committee on Legal Education's ad hoc Advisory Steering Committee on the Review of Legal Education and Training in Hong Kong decided not to pursue this recommendation and rather sought for the two universities to proceed with major reforms of its existing PCLL curricula. ${ }^{106}$

In recent years, the Hong Kong Law Society has again revived the proposal for a common entrance examination to be introduced after the completion of the PCLL, and as an additional hurdle for admission to the solicitors' branch of the legal profession. ${ }^{107}$ This most recent push for a common entrance examination has

\footnotetext{
101 Marsh and Ramsden (n 24) 151-152.

102 Marsh and Ramsden (n 24) 152.

103 Marsh and Ramsden (n 24) 152.

104 Marsh and Ramsden (n 24) 153.

105 Marsh and Ramsden (n 24) 153.

106 Marsh and Ramsden (n 24) 153.

107 Chan (n 23) 1.
} 


\section{LEGAL EDUCATION AND THE REPRODUCTION OF HIERARCHY: A CONTEMPORARY ASIAN READING OF A SEMINAL TEXT}

been met with strong opposition from the universities involved, as well as the Hong Kong Bar Association. The Standing Committee on Legal Education noted in their interim report, for example, "that there was no sufficient or convincing justification for the introduction of a common entrance examination" in Hong Kong. ${ }^{108}$ Johannes Chan, in turn, reminded that since the promulgation of the Legal Practitioners Ordinance Cap 159 of 1964, the powers of the Chief Justice of the then Hong Kong Supreme Court (now Hong Kong Court of Final Appeal) to regulate the practice of law and legal professionals in Hong Kong had only partially been transferred to the Hong Kong Law Society and that any change in admission requirements by the Hong Kong Law Society remained subject to the approval of the Chief Justice. ${ }^{109}$

Given the already highly competitive nature of legal education in the Hong Kong Special Administrative Region, the introduction of an additional hurdle on the path of becoming a legal professional in Hong Kong is indeed questionable. More pertinent concerns regarding the current PCLL programme are rather whether this one-year practical legal training course serves its purpose, and whether practical legal training is a task that falls within the purview of universities. Should the training of practical legal skills not rather fall under the authority of the legal profession by way of its professional bodies - the Hong Kong Law Society and the Hong Kong Bar Association? For example, in 1979, with reference to the practical training for aspiring barristers in England and Wales, Professor Harry Cohen remarked as follows:

The practical formal trial advocacy training the ordinary English bar student receives is questionable, and it is only when he or she enters pupillage that the student may receive good training in Chambers under a barrister who may or may not be a good teacher. This assumes in the first place that the student is "acceptable"'. In fact, there is a great deal of discrimination of all kinds in the process.

This is because universities, particularly publicly funded universities, are in the business of (or should be in the business of) higher education and research, and not vocational training. ${ }^{110}$ Moreover, the gatekeepers of a profession, like that of the legal profession, are the respective professional bodies responsible for

\footnotetext{
108 Chan (n 23) 2.

109 See section 4 of the Legal Practitioners Ordinance Cap 159 and rule 7 of the Trainee Solicitors Rules Cap 159J; Chan (n 23) 8-10.

${ }^{110}$ Harry Cohen, "The Divided Legal Profession in England and Wales - Can Barristers and Solicitors be Fused?” (1987) 12 The Journal of the Legal Profession 7, 16.
} 
regulating the profession and this gatekeeping task is not one in which universities should become too readily involved, by way of, for example, determining admission to a practical legal training programme like the PCLL programme. With regard to the most recent proposal for a common entrance examination one student observed as follows:

Professor Kennedy addresses the issue by suggesting a minimal skill test for admission, which resonates with the reasoning of the implementation of the Common Entrance Examination (CEE) in 2021. The exam can eliminate the discrimination against graduates from a less competent law schools and standardizes the quality of lawyers entering practice. Unfortunately, universities seem to strongly protest against the CEE. Universities wish to maintain their hierarchical status to keep the privilege they have been enjoying, i.e. deciding who to admit as a layer. How ironic is it to resist something that creates a better future and stay obedient to an illegitimate hierarchical education system. (JD student, 2018)

\section{Law School Rankings}

Duncan Kennedy remarked as follows on the role that law school rankings play in the reproduction of hierarchy in legal systems.

The teachers' fundamental structuring practice is the creation and maintenance of a hierarchy of law schools. This involves at least three subpractices: First, law teachers create an ordering of schools according to material resources and faculty academic qualifications (the richest schools tend as a general matter to have the most academically qualified faculty rather than the least qualified). Second, law teachers arrange law school applicants in an ordering according to "corrected" college grades and LSAT scores. Third, law teachers allocate students to schools so that the "better" students go to the "better" schools. The upshot is a system in which some schools have lots of money, "good" teachers and "good" students. Other schools have middling money, teachers and students. The bottom schools have little money, "bad" teachers and "bad" students. (Of course, some schools defy such easy characterisation, but not many. $)^{111}$

This hierarchical reproduction is particularly notable in the context of Hong Kong, a small jurisdiction with all three of its legal education and training

111 Kennedy (n 1) 67. 


\section{LEGAL EDUCATION AND THE REPRODUCTION OF HIERARCHY: A CONTEMPORARY ASIAN READING OF A SEMINAL TEXT}

providers - the Faculty of Law of the University of Hong Kong, the Faculty of Law of the Chinese University of Hong Kong and the School of Law of the City University of Hong Kong - featuring under the top 100 law schools in both the 2019 QS World University Rankings, as well as the Times Higher Education World University Rankings. In the law subject ranking of the 2019 QS World University Rankings, the Faculty of Law of the University of Hong Kong is ranked at 19, the Faculty of Law of the Chinese University of Hong Kong at 40 and the School of Law of the City University of Hong Kong in the 51 to 100 cohort. ${ }^{112}$ And in the law subject ranking of the 2019 Times Higher Education World University Rankings, the Faculty of Law of the University of Hong Kong is ranked at 22, the School of Law of the City University of Hong Kong at 45 and the Faculty of Law of the Chinese University of Hong Kong at 49. ${ }^{113}$ Moreover, these three tertiary education institutions also fare well in terms of the general university rankings with the University of Hong Kong ranked at 25 in the 2019 QS World University Rankings, the Chinese University of Hong Kong at 36 and the City University of Hong Kong at 55. ${ }^{114}$ Of this, students remarked as follows:

If the ranking system of law schools in the USA help create and maintain a hierarchy of law schools as Kennedy argues, the situation is even worse in Hong Kong. The limited number of law schools make it more straightforward for the ranking of them in Hong Kong, and the potential law students are clearly divided into three tiers during the application stage. With the 'best' students going to the 'best' law school and the least capable ones to the third best law school, the hierarchy is so rigid that it is hard if not impossible for a slight change. (JD student, 2019)

In particular, the fact that there are only three law schools in Hong Kong which, from my point of view, reveals a more obvious hierarchy than that in

112 QS World University Rankings 2019 <https://www.topuniversities.com/universities/ subject/law-legal-studies $>$ accessed 31 March 2020.

113 Times Higher Education World University Rankings $2019<\mathrm{https}$ //www. timeshighereducation.com/world-university-rankings/2019/subject-ranking/law\#!/page/0/ length/25/sort_by/rank/sort_order/asc/cols/stats> accessed 31 March 2020.

114 QS World University Rankings 2019 <https://www.topuniversities.com/universities/ country/hong-kong-sar> accessed 31 March 2020; the 2019 Times Higher Education World University Rankings ranked the University of Hong Kong at 36, the Chinese University of Hong Kong at 53, and the City University of Hong Kong at 110; Times Higher Education World University Rankings 2019 <https://www.timeshighereducation. com/world-university-rankings/2019/world-ranking\#!/page/0/length/25/sort_by/rank/ sort_order/asc/cols/stats> accessed 31 March 2020. 
the USA. Not only the law schools itself are competing for the ranking in terms of reputation, resources, affiliation with law firms and so on; their students are also inevitably forced to accept the professional hierarchy and are preoccupied with the ranking status. From the moment they enter law schools, law students become part of the legal hierarchy. (JD student, 2016)

And another observed that "students and teachers are intensely preoccupied with the rankings of schools" (JD student, 2018).

With regard to the fierce competition that also exists among the three law schools/faculties responsible for legal education and training in Hong Kong, it is ironic to note that when the Chinese University of Hong Kong announced on 10 May 2004 that it would be establishing Hong Kong's third law school, both the University of Hong Kong and the City University of Hong Kong remarked that "a larger community of legal scholars and healthy competition among quality law schools would enhance rather than dilute the quality of legal education in Hong Kong". "15 Yet, whether the preoccupation with rankings that currently characterise the legal education and training landscape of Hong Kong fosters quality legal education, is debatable, as will be evident from the discussion below.

\section{FROM LAW SCHOOL TO LEGAL PRACTICE: THE CONTRIBUTION OF LEGAL EDUCATION TO HIERARCHIES IN THE LEGAL PROFESSION OF HONG KONG}

The Hong Kong Special Administrative Region with its estimated population (by end 2018) of 7,482.5 million people, ${ }^{116}$ is currently being served by a legal fraternity comprising approximately 9,757 practising solicitors and 1,611 barristers. ${ }^{117}$ These legal professionals are primarily produced by the three local tertiary institutions responsible for legal education and training in Hong Kong.

\footnotetext{
115 Marsh and Ramsden (n 24) 155.

116 Government of the Hong Kong Special Administrative Region, Census and Statistics Department, 2018 Population Statistics, <https://www.censtatd.gov.hk/hkstat/sub/so20. jsp> accessed 31 March 2020.

117 This data on the number of practicing solicitors and barristers in Hong Kong as well as the data below was obtained from the annual reports of the Hong Kong Law Society and the Hong Kong Bar Association. Hong Kong Law Society Reports available online at <https://www.hklawsoc.org.hk/pub_e/about/report/> accessed 31 March 2020, and Hong Kong Bar Association Reports available online at <https://www.hkba.org/eventspublication/annual-statements $>$ accessed 31 March 2020.
} 
LEGAL EDUCATION AND THE REPRODUCTION OF HIERARCHY: A CONTEMPORARY ASIAN READING OF A SEMINAL TEXT

\begin{tabular}{|c|c|c|c|}
\hline \multicolumn{4}{|c|}{ HONG KONG LAW SOCIETY } \\
\hline & 2016 & 2017 & 2018 \\
\hline Total members & $\begin{array}{l}10,345 \\
\text { (of which } 48 \% \text { of } \\
\text { practicing certificate } \\
\text { holders are female } \\
\text { and } 52 \% \text { male) }\end{array}$ & $\begin{array}{l}10,798 \\
\text { (of which } 48 \% \text { are } \\
\text { female and } 52 \% \\
\text { male) }\end{array}$ & 11,246 \\
\hline $\begin{array}{l}\text { Members with } \\
\text { practicing } \\
\text { certificate }\end{array}$ & $\begin{array}{l}9,076 \\
\text { (of whom } 7,010 \text { were } \\
\text { in private practice) }\end{array}$ & $\begin{array}{l}9,463 \\
\text { (of whom 6,951 } \\
\text { were in private } \\
\text { practice) }\end{array}$ & $\begin{array}{l}9,757 \\
\text { (of whom } 7,413 \\
\text { were in private } \\
\text { practice) }\end{array}$ \\
\hline Trainee solicitors & $\begin{array}{l}646 \text { trainee solicitor } \\
\text { contracts were } \\
\text { registered }\end{array}$ & 1,156 & 1,239 \\
\hline $\begin{array}{l}\text { Registered foreign } \\
\text { lawyers }\end{array}$ & 1,645 & $\begin{array}{l}1,433 \\
\text { (from } 34 \\
\text { jurisdictions) }\end{array}$ & $\begin{array}{l}1,602 \\
\text { (from } 33 \\
\text { jurisdictions) }\end{array}$ \\
\hline \multicolumn{4}{|c|}{ HONG KONG BAR ASSOCIATION } \\
\hline & 2016 & 2017 & 2018 \\
\hline Practising barristers & Unknown & 1420 & 1,611 \\
\hline $\begin{array}{l}\text { Total pupils serving } \\
\text { (pupillage) }\end{array}$ & 174 & 185 & 206 \\
\hline $\begin{array}{l}\text { Number of pupils } \\
\text { having commenced } \\
\text { with pupillage }\end{array}$ & Unknown & 98 & 108 \\
\hline $\begin{array}{l}\text { Number of pupils } \\
\text { admitted as } \\
\text { barristers }\end{array}$ & 84 & 86 & 108 \\
\hline $\begin{array}{l}\text { Number of pupillage } \\
\text { applicants received }\end{array}$ & 595 & 606 & 725 \\
\hline
\end{tabular}

With regard to the reciprocal relationship that exists between the hierarchy in legal education (as discussed in the previous part of this article), and the hierarchy in the legal profession and practice, Duncan Kennedy said the following of the situation in the United States of America:

Legal hierarchy is a typical American phenomenon, rather than something peculiar to law or even to the professions. Law firms and law schools strongly resemble, from the point of view of hierarchy, the other institutions of our society, including state bureaucracies, service corporations, and industry. The 


\section{THE DENNING LAW JOURNAL}

relationship between legal education and law practice is typical of relationships between the parts of the total hierarchical structure that have strong functional, input-output links. And, the ideology of legal hierarchy is no more than a specialized application of the general meritocratic ideology of American society. ${ }^{118}$

This is also true of the situation in Hong Kong, and was described by a JD student as follows:

...within a market driven economy, the principle of supply and demand further substantiates the existence of legal hierarchies, academically and socially. Not only are lawyers attracted to the materialistic rewards of conformity, but also the established firms as well, for their goal is to increase market share. Thus, any attempts of reform would be prevented in void of 'rocking the boat'. Clients have therefore unconsciously shaped the selection requirements for lawyers. Consequently, all that has been criticized by Kennedy is no unique problem to the legal field. (JD student, 2019)

In Hong Kong, most law students aspire to secure a training contract with one of the reputable international law firms in the city. ${ }^{119}$ These firms are usually referred to by the students as the "magic circle" and was described as follows:

Most law students believe that if they work hard enough for a strong GPA, they might join the magic circle. But as I demonstrated, moving up the social ladder is difficult. It's labelled as the magic circle because it segregates people from other social classes than one's own. (JD student, 2018)

The legal field is more hierarchical than any other disciplines. Best students go to the best law school, land at a great Trainee Contract and start their career in the Magic Circle. On the practical side, firms in Hong Kong are divided into various circles according to their frames, histories, traditions and businesses. Magic Circle only has its door open for students with a strong familial background. Silver Circle welcomes those who are professionally trained since a young age. Red Circle is for those who are ready for the Mainland's market. They are the top in the hierarchy. In the middle sit the international firms whereas local firms occupy the lowest deck in the diamond-shape hierarchy as Kennedy described. (JD student, 2019)

\footnotetext{
118 Kennedy (n 1) 100.

119 These are, for example, the firms Clifford Chance, Linklaters, Slaughter and May, Allen \& Overy, Freshfields Bruckhaus Deringer.
} 


\section{LEGAL EDUCATION AND THE REPRODUCTION OF HIERARCHY:}

A CONTEMPORARY ASIAN READING OF A SEMINAL TEXT

Yet, it is not only a good CGPA that will secure a position at a reputable international law firm in Hong Kong. Kennedy noted in his 1983 text that "your chances of ending up at a 'top' law school are directly proportional to your status at birth". ${ }^{120}$ This is all the more true in Hong Kong, and in the discussion below it will be shown how, in addition to grades, social and economic standing, as well as law school ranking, impact on Hong Kong law students' career prospects in the city.

\section{A. Social Mobility and Social Aspirations: Doomed for the Legal Hierarchy}

In the introduction to this article, the perceived social prestige and status associated with studying law and entering the legal profession, and the potential gain this may hold for a "family's cultural capital", especially in East Asian societies, were elaborated upon. The positive correlation that exists between socio-economic status and academic performance was furthermore noted in Part IIIA of this article in the context of law school admission processes and the advantage students from wealthier families have in this regard. The exorbitant cost of the various law degree programmes, which makes it difficult for those from the lower socio-economic strata of Hong Kong society to qualify as a legal professional, was also considered in Part IIIA. In addition to these, Hong Kong law students also suggested that the local and international law firms and the various chambers in Hong Kong favour students with a particular social standing and background when considering whether to offer a training contract or pupillage position.

One's status is not only determined by the GPA, but also, whether he/she is a rainmaker or not, in other words, firms always value those who can bring new business opportunity to the company. Since wealthy family own more resources and have the broader social network, it makes sense that their children benefit from these advantages, thereby, strengthen their social status. (JD student, 2018)

Students with an upper-class family background will have an upper hand. They tend to know people from the law industry, be it due to similar social status or they are themselves a client of those firms. These spider-web relationship is part of the critical success factors for law firms. In fact, job placement of clients' children is no stranger to industries that rely heavily on client relationship like the private bank industry. (JD student, 2018)

120 Kennedy (n 1) 54. 
The most authoritative lawyer in the market only choose the top students who are usually from wealthy family and high social status. The economic ability of the student's family is crucial if the student chooses in qualifying as a barrister. Without the family financial support, there is no way to sustain from being a free labour for a year or more. (JD student, 2018)

The law industry relies heavily on network and personal relationships. Students with parents or relatives at the law profession are at great advantages, as they are exposed to more support and connections. Law firms favour students with legacies for two reasons. First, the law industry itself is a commercial practice. A student or future employee with strong networks are potential client bases. Second, lawyers are professionals whose reputation are main sources of income. Training ones whose family members are closely related to the industry proves it less risk on wasting time and resources on unsuitable individuals. To law firms, there is certainly no doubt in deciding who, with similar grades and skills, are better candidates. ...status at birth is directly proportional to chances of being in a top law school and unfortunately, the phenomenon extends to the whole industry. ...At the end of the day, the likelihood of a lower social class student trespassing ...is exceptionally low, and even if one beats the odds, the career does not prove it any easier in an industry that is so heavily network based. (JD student, 2019)

"The first class in law school usually is a self-introduction session, one of my classmates said that her parents are both solicitors. I can never stop reflecting the confidence in her eyes... (JD student, 2019)

This situation stands in stark contrast to the situation in the People's Republic of China, which was described by two JD students as follows:

In China, legal education could be a means for a student to change class. National Jurist Exam is available and equal to all law school graduates. Law school students would not worry about whether teachers like them or not as they don't have to get high GPA for the qualified exam. Students could challenge their teachers, and they could have their own ideas. Lower class students always have the chance to become a lawyer and shift to a higher class if they keep trying, which can weakened the hierarchy. (JD student, 2018)

The first is the Hong Kong culture, including language and White Supremacy. ... in Hong Kong, after attend some alumni activities, I realised that without fluent Cantonese one can hardly be a barrister in Hong Kong, although we are all Asian face; however, with a 'white fact' you can do 'whatever you want' in the law society in Hong Kong. This is a ridiculous but also a fact. You may be a middle or upper class in mainland, as long as you are 


\section{LEGAL EDUCATION AND THE REPRODUCTION OF HIERARCHY:}

A CONTEMPORARY ASIAN READING OF A SEMINAL TEXT

not able to speak Cantonese or you don't have a 'white face', you will have a lot of barriers in pursuing your law career in Hong Kong. (JD student, 2019)

Indeed, despite the overt emphasis being placed on academic achievement in gaining admission to study law and ultimately joining the legal profession in Hong Kong, it seems "being clever" is indeed not enough.

However, we need to rethink whether a position in society is an indicator to determine your ability. If so, upward mobility only belongs to those people with superior position in society, and all the law firm would entirely ignore your effort on the legal study. (JD student, 2019)

\section{B. The Impact of Law School Rankings on Students Career Paths}

Hong Kong law students are seemingly acutely aware of the direct impact law school rankings have on their future career paths, and specifically their prospects in securing a training contract or pupillage in Hong Kong.

As law firms, especially the ones that have already occupied high market share, they per se want hierarchy in the competing market of legal service, which make it easier for them to attract and convince the high level clients. And what else can be the standards of the top law firms besides knowledge, service, relationship and scale of fees? The answer may be their standard of requirement, and one of the easiest ways to distinguish the resumes of the graduates is by their education background, as a result, the hierarchy of law schools will be formed among the market, which is good news for top law schools because employment rate is one of the important evaluation indexes. What's more, the relationship of alumni is a kind of resources for both schools and graduates, which can be seen in the official websites of the universities. Partners are usually willing to hire their alumni partly because they want to help their schools raise their employment rate and reputation. ...As a student that graduates from a lower-class law school in Mainland, it is now very difficult for me to get an internship even in the outstanding but not the top law firms. It seems that you should go forward step by step, if one of your steps is wrong, for which you have to pay a lot. (JD student, 2018)

Other students were far less circumspect in their observations of how law school rankings impact on their future career path, and gave unembellished accounts of their experiences as law students from the law school with the lowest rank in the city - the City University of Hong Kong. The observations and personal 
anecdotes of students included here are so powerful and illustrative of the reproduction of hierarchy from law school to the legal profession that it does not deserve any further contextualisation and are rather included here in extenso:

In $\mathrm{HK}$, receiving a degree from HKU practically guarantees any candidate a spot in the "Magic Circle". While CityU has improved in rankings, culturally, it is still quite stigmatized. ...Speaking to different partners and associate, many agree that although CityU has produced successful lawyers, it is the "name" of the school that prevents firms from accepting promising individuals. For example, chambers such as Temple or Des Voeux only accept Oxford and Cambridge graduates. (JD student, 2019)

HKU graduates are much more likely to practice in famous or city firms and specialise in high-prestige fields of law mainly due to its higher reputation and the large proportion of its graduates practicing in HK. I once did minipupillage in a famous chambers in HK where I surprisingly found that all barristers graduated from HKU. From daily talks with my classmates, it seems that students have now accepted that HKU graduates are enjoying that "privilege". (JD student, 2016)

Thanks to the arrangement of the Law School, we are frequently exposed to opportunities in joining open house events in those top-tiered law firms. A bit to our puzzle, the interns and trainees from local law schools being put on stage are almost all from the 2 top-tiered law schools in the territory. If GPA is a universal benchmark, then where have those from CityU [...] disappeared into? From my perspective as a retired experienced management staff with on-going recruitment responsibilities, I do think that, to certain extent, there are glass ceilings in the recruitment process. There exists a subconscious (if not conscious) bias of the alumni recruiters to prefer those from their same top-tiered law schools as it will further reinforce the power of the same background in the firm. When everything stands equal vs other students who have a strong alumni or top-tiered school background, you need to strive extra hard if not till your last breath to impress the recruiter of your ability. (JD student, 2018)

My experience at an Open House event of elite law firms reflects upon this phenomenon. Based on the presentation, I can tell there is a clear sense of the hierarchical role of lawyers in society, since it is common practice for opt law firms to recruit students from the top two law schools and to overlook students from the third ranked school. As a result, students from top law schools have already assured their superiority in the society by making more money, exercising more authority than students from lower ranked schools. (JD student, 2018) 
LEGAL EDUCATION AND THE REPRODUCTION OF HIERARCHY: A CONTEMPORARY ASIAN READING OF A SEMINAL TEXT

Last semester, I went to the Law Fair in Wan Chai. Whilst being overwhelmed by the number of exhibitors and how keen they were to give away merchandise and talk about their firm, I was more overwhelmed by some of their reaction when I revealed to them that I am a law student from City University. Most of them after talking to me for a few minutes, changed their tone and attitude from a keen and optimistic tone to being rather sympathetic to the point of pitying me. I remember one of them said to me "Look, you are a nice girl but the reality is [...] it will be really hard for you to get a training contract I'm afraid," which still rings in my ear. If students from what is seen as a lower ranked law school is judged against a bias, then ultimately the hierarchy of law schools will give rise to a hierarchy between lawyers as which law school you went to will stick with you through the rest of your career. (JD student, 2019)

...I had seen a lot many senior partners like to ask where did the trainees or junior associate graduate or where did they work before? They beautify it as searching their law school fellows. However, legal secretaries clearly know that they are actually categorizing people from different law schools to estimate or judge their working ability. Such categorization creates an "invisible" hierarchy among the staff from the same batch of trainees to the senior associates. (JD student, 2018)

I participated in the Hong Kong Law Fair 2017, where booths of reputable international firms were set up for enquiries and law students from different universities would interact with the firms' representatives. I approached one trainee solicitor and gave a self-introduction. Once he knew which university I was from, he walked away instantly, most probably because of the "lower prestige" of my university. His conduct was, not only disrespectful but also the best proof of Duncan Kennedy's words - "where you went to law school... seem to make an enormous difference to where you can get a job". The school/ firm hierarchy has seemingly prescribed our future before we could realise what is going on. (JD student, 2018)

\section{WHY (THE REPRODUCTION OF) HIERARCHIES IN LAW AND LEGAL PRACTICE ARE BAD: THE CASE OF THE HONG KONG SPECIAL ADMINISTRATIVE REGION}

It is submitted that the existing and reinforced hierarchies of the legal (education) system and the legal profession of the Hong Kong Special Administrative Region have far-reaching consequences not only for those trying to make their way up 
through the hierarchy, but also for the city and all its residents. Of this Duncan Kennedy said:

The denial of hierarchy is false consciousness. The problem is not whether hierarchy is there, but how to understand it, and what its implications are for political action. [...] Anyone who wields social power, including all lawyers and all law teachers, constantly influences the choices of others, and no amount of respect for diversity can exempt from responsibility of that influence. ${ }^{121}$

\section{A. When Grades Define Worth}

The overt obsession with and focus on grades and rankings in the legal education and training system of Hong Kong was evident from the discussion in the preceding parts of this article. It was also shown that these grades and rankings are often the primary determinative factors in the decisions of law firms and chambers when respectively offering training contracts or pupillage positions. This continuous reproduction of hierarchy from pre-university education, throughout students' university training, and also when they compete on the job market was remarked upon as follows by JD students:

Acceptances into the postgraduate program relies on the undergraduate mark achieved, above a cut-off grade. Internship applications rely on the GPA achieved, above a minimum requirement. Potential job offers I choose to accept would rely on how highly ranked the firms are, with one being above the other. When I achieve the seniority to choose interns, I would look at their grades, choosing the best one among them, and thus restarting the cycle. From the education system, to the law degree, to the internships, to the firms, the idea reaffirmed is that I must be the top one, because all future hierarchies are dependent on the concept of "best" and "top". The better numbers I achieve, whether in the form of a grade or a ranking, the better I will do in the future, as a lawyer. (JD student, 2018)

...These grades in return determine where a student will work in the future, their salary, and their standard of living. This is especially true in the first year, where students are experimental and unsure of how the system works. Therefore can it be said good results are based on how fast you "get" the system and perhaps "luck"? There seems to be no second chances in the grading system and it is almost impossible to change your rank amongst students. (JD student, 2016)

121 Kennedy (n 1) 95 and 110-111. 


\section{LEGAL EDUCATION AND THE REPRODUCTION OF HIERARCHY: A CONTEMPORARY ASIAN READING OF A SEMINAL TEXT}

It is submitted that this overt focus on grades and academic achievement at all stages of the legal education and training system of the Hong Kong Special Administrative Region is currently doing more harm than good. It excludes worthy aspiring candidates based only on academic merit, and without adequately taking into consideration the various other qualities - other than academic achievement successful legal professionals must ultimately possess. These include, for example, qualities like empathy and compassion, the ability to communicate effectively with people from all walks of life, strong ethical values, and an exemplary work ethic and commitment to serve in a profession which essentially exists for the interests of society. In Hong Kong, an overt focus on grades and academic achievement which remains ignorant of the necessary and valuable advantages diversity has to offer runs the risk of (further) establishing an elitist law study body and legal fraternity for the Special Administrative Region. It also deprives Hong Kong law students from an important experience whilst at university; the joys of fostering real connections with fellow students, belonging to a collective student body and sharing educational experiences.

Amongst students, the competition is intense. Over time, a hierarchical structure, i.e. "class rank" is recognised amongst classmates, through awareness of one another's class performance and grades. There is a lack of desire and a sense of reservation to help others. Moreover, this system creates a situation in which most students are only interested in examinable material, rather than wanting to gain an understanding beyond the confinements of the syllabus. (JD student, 2016)

Particularly crucial is the dire effect this overt focus on grades and academic achievement have on the emotional well-being of students:

...students are merely their results [CGPA] under the hierarchy. (JD student, 2016)

The concept of hierarchy begins to grow in our mind from the moment that we label ourselves as either superior or inferior according to our grades and school. I used to be a confident person who was convinced that artificial numbers such as my GPA, the ranking of my university do not define my value. But law school persuaded me the opposite. Here, GPA and university's ranking are essentially everything, for they determine my admission to PCLL and my entire legal career. Consequently, due to my relatively poorer results, my confidence faded. I frantically considered myself inferior to my classmates. It was tragic of how quickly I started to accept and position myself in the hierarchy under intense competition. (JD student, 2018) 
One of the students remarked as follows:

The issue with esteem, in the legal education, is the lack thereof. ...When will we, as students, ever be able to reach self-actualisation, seeking personal growth and experience, and not just a blind pursuit of grades and numbers. (JD student, 2018)

This student also stated that "the legitimacy of a legal profession that purports to generate a better, grand society, would require the fulfilment of selfactualisation", in other words, the law cannot only strive towards social transformation, it must enact the transformation it wishes to achieve first in itself.

In addition, given how important and determinative grades and the coveted CGPA ultimately are for the future career paths of students, an overt focus on grades and academic achievement unfortunately also impact on how students approach their learning experience at university. Many students observed, for example, that it has become so important to achieve a high grade, that they would rather follow their lecturer or tutor's instructions exactly, almost mechanically, than allow themselves to reflect more freely on their legal studies and practice their critical and independent reasoning skills.

Hong Kong's education system have rewarded students with 'right' answers and penalised "wrong" answers since elementary level, and hence individuals approach legal studies attempting to search for "right" answers, neglecting the process as to how such answers are derived. For example, students often examine cases merely by the ratio, rather than closely examining the legal reasoning which the ratio is derived from or how the case fits into the law as a system. (JD student 2016)

...in the grading system of law school, we need to closely follow professors' instructions in each course in order to get good grade. The grade level determines whether we could get into PCLL and whether we could get interview chances from top law firms in Hong Kong. (JD student, 2016)

...the classification of the hierarchy in law school may let all students lose the ability to judge themselves objectively. The ambition for higher classification brings a strong feeling that their own thoughts on law are not important and useless to help them to get a good mark. And it is not the aim for any reasonable person to start legal education. (JD student, 2018)

This grade-centric regime incapacitates students' critical thinking ability, as they are so eager to accommodate examiners' academic preferences, in order to score the highest marks possible, which breeds academic deference. (JD student, 2018) 


\section{LEGAL EDUCATION AND THE REPRODUCTION OF HIERARCHY: A CONTEMPORARY ASIAN READING OF A SEMINAL TEXT}

The existence of such hierarchy defeats the whole purpose of legal education, one that should enable students to think differently from layman by encouraging them to read wide and develop a general appreciation for the law. However, HK students are only reading the minds and preferences of their professors. The need for good grades and to be associated with the 'upper' crowd is what I believe to be the culprit for producing lawyers that are book-smart yet lack the ability to think independently and critically. ... For a legal education to produce its true value, it is essential that ... greater emphasis [is placed] on the person as a whole but not just their GPA. (JD student, 2019)

Hence, instead of studying in the areas that we are interested in, we tend to study subjects with easier curriculum or good grading. (JD student, 2019)

Hence students become paranoid as to their grades, conforming the "intense awareness" and "endless comparisons" Kennedy talks about. Many will do whatever it takes to achieve a high GPA. They become reluctant to voice out their true thoughts, fearing that it might affect their grades if the marker did not like it. They also do and believe whatever they are asked or told. They become exam machines, generating high marks without really absorbing what is being taught, and when practicing in the real world, they are often being referred to as "high-grade retards". (JD student, 2016)

Curiously, this grade-obsession prevailing amongst the law students participating in this exercise can be juxtaposed with that of medical education and training in Hong Kong, of which a JD student observed as follows:

In medical school, there are no grades nor class rankings. While evaluation of students' performances is based on a standard benchmark, students are freed from competition, and we tend to help each other and learn for our future instead for exams. ...I sometimes wonder whether the letter grade on my transcript is a fair evaluation of my legal knowledge and how much they can translate in the real world. As Kennedy criticized, the grading system in law schools is irrelevant to what students will do as lawyers, but only makes students of becoming exam machines and promotes hierarchy during when they feel hopeless if fail an exam. ... Since grading is the simplest evaluation method, it sends a message that only those who attain better numerical results are more competent in becoming corporate lawyers, while those with poorer results aren't fit to be lawyers; indirectly creating a social hierarchy. (JD student, 2018) 


\section{B. It is all About the Money, or Is It?}

Indeed, in most free market economies the competition for employment is fierce, but even more so in the Hong Kong Special Administrative Region where a "business first" or "business above all" attitude reigns supreme. In the introduction to this article, it was noted that Hong Kong's distinctive economic and social status and ongoing development are deeply rooted in its history and have found inculcation in its Basic Law, the mini-Constitution of the Hong Kong Special Administrative Region. ${ }^{122}$ Goodstadt explains that "there was never any doubt about the government's ultimate priority", from the early colonial days to date, and " in almost all aspects of public life' it has been claimed, 'Hong Kong is about business" ". ${ }^{123}$ As to the rationale for, or impetus behind this commitment to economic growth at all costs, Goodstadt states that it always "went hand in hand with an obsession with the perceived dangers of welfarism": 124

Anti-welfarism was so potent an element in the preconceptions shared by officials and business leaders alike because it reflected an even more compelling concern: welfare seemed unaffordable because both groups were convinced of the fragility of Hong Kong and its success. [...] The fear of what the future holds remains a dominant sentiment. [...] This sense of vulnerability reinforces resistance to any tendency towards a higher priority for the social services. ${ }^{125}$

In preserving so much of Hong Kong's past in the Basic Law and in terms of the principle one country to systems until 2047, the overt colonial businessmentality and commerce-focus at all cost continue to dominate much of contemporary Hong Kong life, administration and culture, and therefore also its law and legal (education) system.

From the perspective of the colonial government, and now the Chinese-Hong Kong government, it's more stable and thus desirable if the Hongkongers chase after money than political and civil rights that are too dangerous for the regime

\footnotetext{
122 See Chapter V of the Basic Law of the Hong Kong Special Administrative Region of the People's Republic of China, <https://www.basiclaw.gov.hk/en/basiclawtext/index. html> accessed 1 April 2020.

123 Goodstadt (n 16) 10, quoting from David Mole, "Introduction", in David Mole (ed), Managing the New Hong Kong Economy (Oxford University Press 1996) 4.

124 Goodstadt (n 16) 10.

125 Goodstadt (n 16) 13 and 20.
} 


\section{LEGAL EDUCATION AND THE REPRODUCTION OF HIERARCHY:}

to effectively control the place. This, in my opinion, has a great impact on how its legal education has been conducted. You won't be surprised to find law schools in Hong Kong offer a great variety of business law courses, investment law, trade law, just to name a few, whereas different human right law courses are in the minority on the course list. As a result, law students in Hong Kong are well equipped with skills needed in the corporate business environment. However, as one of the fundamental aims of legal education is to achieve justice, if legal education is used as a tool mainly to achieve economic purposes of society, it leads us to ponder whether we are achieving these at the expense of social justice, such as class and gender inequalities in practice? And to use Kennedy's words, are we actually paying endless attention to trees at the expense of forests? To Kennedy, law school is a training place for those willing to work in the hierarchical corporate welfare state and it generates collective passivity in the disguise of fairness which perpetuate class, racial subordination and gender inequality. From my observations, this is also the situation in Hong Kong, but I would say not just the legal education, but the entire education system, that we are training the legal professionals and others serving for the economic needs of our society and we tend to care less whether we are creating any sort of inequalities or hierarchies in the process. Although creating hierarchies is not necessarily a bad thing for societies to work well, we need to bear in mind that legal education and education system as a whole should aim to educate people with critical minds and not to generate collective passivity in the disguise of fairness. (JD student, 2016)

Given, therefore, that most of what happens in Hong Kong, or does not happen in Hong Kong, is prompted primarily by or for the advancement of the commercial sector, large corporate law firms hold a particular allure for law students, leaving those who are unable to secure a position in a top international law firm seemingly forever doomed with a career "at the lower end of the market" (JD student, 2018).

In Hong Kong, GPA is vital for law students to apply the license required program PCLL, and it is even the line to differentiating students from getting into a decent international firm or a crappy local firm. (JD student, 2016)

...there is much emphasis on hard work and performance, which will in turn be rewarded. There were no reasons given as to why one should choose an international over a local law firm apart from the salary and prestige; furthermore, choosing to become a human rights or criminal lawyer was to be "brave choices". (JD student, 2016) 
In the first semester, we were petrified by professors who told us that without entering a top international law firm in the very beginning of career, we will always be 'stuck' at local law firms for the rest of our law career. Since then, we have been categorised among peers with labels of "potential international firm" and "local firm" on our foreheads through daily performance and coursework grades. (JD student, 2016)

Students furthermore noted that this hierarchy or preference is mirrored in the courses on offer in their law programmes; it being "largely shaped by the economic interests in Hong Kong" (JD student, 2018).

To remain competitive, law schools also follow the job market closely and oblige students to learn extensively about the commercial world. Those who wish to become a qualified lawyer in Hong Kong are required to take certain courses as part of the admission requirement. However, a majority of the core mandatory courses are gearing towards corporate practices; for instance, company law, commercial law, equity and trust and more. ...students are required to spend considerably more time on business-related courses, which tailor to the needs of international law firms. ... The system portrays that business-oriented practices are important but others are relatively insignificant. This hierarchy highlights the differences in social class. ... Ultimately, students in Hong Kong are convinced that corporate practice is seemingly a better career choice while practicing in other specialities would be portrayed as less competent. (JD Student, 2018)

The syllabus design gears students to be end products for the benefits of employers whose hierarchical corporate cultures infiltrate the students' minds before they graduate through career talks, open houses and interview skills workshops. (JD student, 2018)

From my observation, my class mates prefer taking courses like Commercial Law, Banking Law, Intellectual Property law and so on. It is partially driven by students dominant in college who mainly composed of higher level of business and political family background. It is therefore understandable for higher demand of more practical and commercial courses. The trend is also pushed by profit-driven culture of the economic-based environment where we are raised and taught to go for raising our social status and financial status. (JD student, 2018)

Most of the courses are designed for corporate lawyer, so as the career events of the school, students who are not aim for the same has their career path and possibilities being limited and moulded. By following this training, students become machinery and loss their true colour. (JD student, 2019) 


\section{LEGAL EDUCATION AND THE REPRODUCTION OF HIERARCHY: A CONTEMPORARY ASIAN READING OF A SEMINAL TEXT}

Ultimately, this extreme business-mentality and commerce focus seemingly train law students not only for the hierarchy, but distinctly for commercial practice:

My first impression about law school is not just hierarchical oppression, but hypocrisy. It all began during orientation when students said they wanted to serve justice. I can tell some of them were genuinely, perhaps idealistically, aspired to turn social injustice on its head, yet most of them, after just one semester elapsed, have turned their aims to becoming a lawyer at corporate firms, where their size depends on grading - the best student aims to enter magic circle while the rest settles for local firm. ...Asking anyone to consider non-profit organization, such as the Legal Aid Department, will make you look ludicrous. (JD Student, 2018)

...this is a vicious cycle that makes law schools manufacture 'corporate lawyer clones' cohort after cohort that all wanted to squeeze into top law firms. The design of law programmes forces students with no choice but moulded into lawyers the society wants them to be. (JD student, 2019)

Legal education and training in the Hong Kong Special Administrative Region should therefore take care in not also turning a blind eye to social development and justice in deference to a "business first" attitude. And while there are examples of best practices fostering social awareness amongst law students and enabling students to also pursue careers beyond commercial legal practice, ${ }^{126}$ much more can - and should - be done. In fact, this much was already noted in the 2001 Redmond-Roper report referred to earlier in this article, and in which it was submitted that "legal education should be capable of adapting to meet the needs of different segments of Hong Kong society. Legal education in Hong Kong was [referring to the time of the report (2001)] essentially geared towards addressing the needs of the market economy. Yet Hong Kong is more than just an economy, it is a modern, complex society with residents who have a vast range of legal needs. It is incumbent on law schools to equip graduates with the knowledge and skills to help identify and address unmet legal needs". 127

\footnotetext{
126 These best practices include the following: Some of the mixed-degree programmes offered by the Faculty of Law of the University of Hong Kong and mentioned earlier in this article allow students to explore and prepare for a range of possible careers in law, beyond that of commercial legal practice. The Faculty of Law of the Chinese University of Hong Kong has also made concerted efforts in fostering civic engagement in its law curriculum design. See, for example, Marsh and Ramsden, supra note 65, at 57-65.

127 Marsh and Ramsden, supra note 65, at 59, referring to Steering Committee on the Review of Legal Education and Training in Hong Kong, supra note 53 at 72 and 78.
} 
As a matter of usual practice, law schools would always channel students into jobs in the hierarchy of legal profession according to their own standing in the hierarchy of schools; and suggest top students to join large firms for big money, but without training students who to run a small law business or to enjoy the feeling of independence and moral integrity that comes of creating their own job to serve their goals. ...In fact, legal education as gradually developed in an unhealthy direction that is not for helping the oppressed but only for profitgaining. Such circumstance is not what legal education desire to establish. (JD student, 2018)

Indeed, what the Hong Kong law schools taught are no more than the legal rules and legal reasoning. In other words, a law degree can be meaningless for a graduate whose application for PCLL has been rejected. He may have never gained enough useful knowledge or skills after obtaining a LLB or JD degree from the three law schools. More importantly, the legal education in Hong Kong may not have given the law students a clear aim except pursuing a legal career as a solicitor. (JD student, 2018)

Most ironically, at a mock interview, based on an NGO scenario, I was advised to get myself a 'glamourous internship' at this point of time. However, there would be limited social value to put every law student on track to become extravagantly-paid corporate lawyers, in arranging commercial deals. The market economy is important, but what about people without access to affordable legal services? ...I have always wanted to be a judge, because this role exudes impartiality and integrity. Unfortunately, it was hardly endorsed as a pursuable legal career. I also wanted to help minorities gain access to legal services, but I was often told that it would not earn much money, and would be disproportionate to my huge tuition investment on my legal education. (JD student, 2018)

Of a narrow trade mentality in legal education and training, one JD student posed a fair warning for the future:

The impact of technology advancement may shake the long-existed hierarchy and bring some changes to the legal education as well. Nowadays, the line between a "profession" and an "occupation" is becoming unclear. It would be an old-fashioned mindset if law schools are only treated as the breeding ground of the legal "profession". Due to the advancement of AI and machine learning, some of the tasks (such as contract review), which have to be done by lawyers, can now be handled by AI-powered software with even higher efficiency and accuracy. Therefore, some commentators have claimed that lawyers might be one of the jobs that will be largely substituted by AI in the 


\section{LEGAL EDUCATION AND THE REPRODUCTION OF HIERARCHY:}

A CONTEMPORARY ASIAN READING OF A SEMINAL TEXT

future. Although I do not take such a pessimistic view, I think being a lawyer would be shifting from being a "profession" to be an "occupation" in the foreseeable future. Therefore, it is necessary for the law schools to get prepare for the challenge and adjust the legal education accordingly in order to adopt the changing world. (JD student, 2019)

\section{CONCLUSION}

This article offered a polemic against legal education in the Hong Kong Special Administrative Region, in the spirit of the Critical Legal Studies movement of the mid- to late 20th century, and utilised a narrative methodology whereby Hong Kong law students conveyed - in their own words - the power struggles they experience and observe in higher legal education and training, and the legal profession. The narratives presented in this article were collected over a period of four years, during which time a selection of postgraduate law students from one of the (three) higher education institutions responsible for legal education and training in Hong Kong were asked to reflect upon their legal studies and future roles as legal professionals with reference to the 1983 self-published pamphlet by Duncan Kennedy, entitled "Legal Education and the Reproduction of Hierarchy: A Polemic Against the System". Kennedy's essay offered a critical analysis of the role of legal education in American social life at that time, and the manner in which it reproduced hierarchy in law, legal education, the legal profession, as well as in society generally. Curiously, the narratives of 21st century Hong Kong law students presented in this article reflect many communalities with the views and experiences of Duncan Kennedy.

Whether perceived or real, the observations, experiences and remarks of postgraduate law students (JD, LLM and PhD) at the School of Law, City University of Hong Kong, professed of the various hierarchies they face on their career path to becoming a legal professional in Hong Kong. Class, social and economic inequalities, an overt focus on grades and academic achievement, law school rankings, and a pervasive "business first" attitude not only mirror the observations of Duncan Kennedy in his seminal 1983 text entitled "Legal Education and the Reproduction of Hierarchy: A Polemic Against the System", ${ }^{128}$ but also seem intensified in the more condensed locale of Hong Kong. One student remarked that legal education and training, as well as legal practice in the Hong Kong Special Administrative Region, are largely "the game of the elite" (JD student, 2019), while another explained as follows:

128 Kennedy (n 1) 1. 


\section{THE DENNING LAW JOURNAL}

The situation in Hong Kong is similar to the USA, albeit more tense and competitive in Hong Kong due to a small market and a large number of law graduates. (JD student, 2016)

The goal of the Jurisprudence assignment requiring of Hong Kong law students to reflect on their legal studies with reference to the Duncan Kennedy text was modest. Maybe it was just to give students the opportunity to critically reflect on, and be honest about the hierarchy in which they have become an unintended participant. Indeed, most students seemed constrained and conditioned by the hierarchies of law school life and legal practice in which they found themselves:

Honestly speaking, before reading Kennedy's article I was 'unaware' of such hierarchy. I was 'unaware' of it because I have already adapted to such an 'ecosystem'. Sadly, I do not think that I, as a student, can change anything at all. Perhaps the only thing I should do is to better equip myself, so that I can have a better chance to achieve a higher hierarchy. (JD student, 2016)

Truth be told, I as a student, will still prioritise my GPA over anything else; so, I do appreciate this opportunity to be honest because such hierarchy is more than a fact in Hong Kong as it has been entrenched into the cultural fabric of Hong Kong. (JD student, 2018)

Because what, if anything can be done once we have identified that these hierarchies as described by Duncan Kennedy in 1983 United States of America, also (still) exist in the Hong Kong Special Administrative Region?

...it is impossible to change it." (JD student, 2018)

...is deeply rooted in the nature of the society therefore it is unavoidable and difficult to have a radical change. (JD student, 2018)

...we [are] disgusted by hierarchy, but we are...compelled to participate. (LLM student, 2018)

However, rank seems to be a culture that has been pre-determined and ingrained in people in the legal industry since a long time ago. Ultimately and inevitably, the legal education system in Hong Kong will continue to produce hierarchies unless a drastic change in the system occurs. (JD student, 2019)

Once climbed up to the top of the hierarchy, no one will make a change, because they have already been the biggest stakeholders. As thus, reproduction of the hierarchy sets in. (JD student, 2019)

We know the problem of the system but we do not have the courage to start the revolution because we all depend on and benefit from the hierarchy, and 


\section{LEGAL EDUCATION AND THE REPRODUCTION OF HIERARCHY:}

A CONTEMPORARY ASIAN READING OF A SEMINAL TEXT

the change actually makes us afraid...maybe the unchanged system itself is the best answer to the question. (JD student, 2018)

Duncan Kennedy in his 1983 essay made recommendations as to how legal education and training can be reconceived to address some of the hierarchies he identified. Yet, Kennedy's 1983 essay failed to bring about any real change in how law schools go about their business as cogs in the apparatus of social hierarchy. This futility was also noted in the student narratives informing this article:

I would not suggest that legal education hierarchy to be hated, at least we are conscious of what we are doing. (JD student, 2018)

Hierarchy inevitably exists, yet it only affect us if we allow it to be so. While I cannot alter the external parties' perception of me, I refuse to subordinate to the system by believing that I stand lower or higher than the others because of my GPA and background. So at least, in my heart, I am no longer a part of it. After all, whether this legal hierarchy is a fact or a myth, simply depends on how we view it. (JD student, 2018)

The narratives included in this article seemingly rather suggest that a good starting point is to explicitly identify and recognise the hierarchies that exist in law, legal education and legal practice. The problem is ultimately "not whether hierarchy is there, but [rather] how to understand it, and what its implications are for political action". ${ }^{29}$ This too was recognised by Duncan Kennedy, who explained:

It is not important for our purpose here to get the picture just right - no one really knows what's going on anyway. The point is rather that some version of the hierarchical reality of the bar impinges on everything that happens to students from about the middle of the first year through graduation. One cannot grasp the political significance of legal education without understanding that the future is present within every moment of a student's experience. Students themselves, through their activities after they graduate from law school, reproduce this very world, with amazingly little change from generation to generation. The system is there only because they remake it anew every day. They do this in part because law schools persuade them that it is the best possible system, while at the same time disabling them, individually and

129 Kennedy (n 1) 93. 
collectively, from doing anything effective against it if the ideology doesn't "take". 130

It is submitted that ultimately all of us who find ourselves participants in this hierarchy, whether intended or unintended, must take responsibility for our "hierarchical behaviour"131 because:

[w] hat is really sad is that inequality and injustice within legal profession is the biggest departure from law itself. What is needed is to think about law in a way that will allow more people to enter into it, to criticize without utterly rejecting it and manipulate it without self-abandonment. (PhD student, 2019)

130 Kennedy (n 1) 60.

131 Kennedy (n 1) 75. 